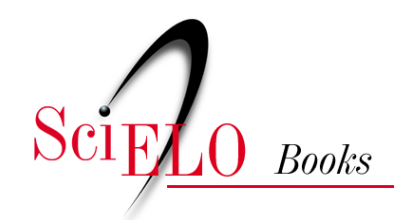

EDUFU

\title{
As formas do viver no Sertão
}

\author{
Luís Augusto Bustamante Lourenço
}

\section{SciELO Books / SciELO Livros / SciELO Libros}

LOURENÇO, L.A.B. As formas do viver no Sertão. In: A oeste das minas: escravos, índios e homens livres numa fronteira oitocentista Triângulo Mineiro (1750-1861) [online]. Uberlândia: EDUFU, 2005, pp. 171-224. ISBN 978-85-7078-516-9. https://doi.org/10.7476/9788570785169.0006.

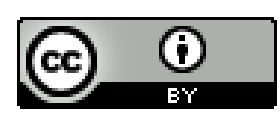

All the contents of this work, except where otherwise noted, is licensed under a Creative Commons Attribution 4.0 International license.

Todo o conteúdo deste trabalho, exceto quando houver ressalva, é publicado sob a licença Creative Commons Atribição 4.0.

Todo el contenido de esta obra, excepto donde se indique lo contrario, está bajo licencia de la licencia $\underline{\text { Creative Commons }}$ $\underline{\text { Reconocimento 4.0. }}$. 


\section{As formas do viver no sertão}

\section{A dimensão da técnica na Geografia Histórica}

No primeiro capítulo de A Natureza do Espaço, obra em que faz a sistematização de seu pensamento, Milton Santos (1996) discute a importância da técnica para a apreensão do conceito de espaço. Segundo o autor, a técnica é a forma como as sociedades operam no espaço. Mas ela não é só isso: a técnica é, ela própria, um meio, isto é, as sociedades, ao utilizarem-na, criam um novo meio natural. As técnicas são os objetos que compõem o espaço, mas objetos prenhes de conteúdo, isto é, só fazem sentido à medida que são usados pelos atores sociais.

Santos fala então em formas-conteúdo: os objetos (formas) só são técnicos por terem uma lógica que os aciona, arranjados num todo coerente (conteúdo). O espaço, na concepção miltoniana, seria composto por essas formas-conteúdo. Os objetos técnicos propagam-se no espaço na forma de sistemas técnicos, isto é, conjuntos de elementos técnicos historicamente datados. Toda técnica, nesse sentido, ao difundirse ou surgir num determinado lugar, o faz segundo as condições históricas que ali operam: a técnica é a síntese da história no espaço. Nas palavras de Santos:

Toda situação é uma construção real que admite uma construção lógica, cujo entendimento passa pela história da sua produção. O recurso à técnica deve permitir identificar e classificar os elementos que constroem tais situações. Esses elementos são os dados históricos e toda técnica inclui história. $\mathrm{Na}$ realidade, toda técnica é história embutida. Através dos objetos, a técnica é história no momento da sua criação e no de sua instalação e revela o encontro, em cada lugar, das condições históricas (econômicas, sócio-culturais, políticas, geográficas) que permitiram a chegada desses objetos e presidiram à sua operação. A técnica é tempo congelado e revela uma história (1996, p. 40).

O autor afirma que o tempo dos sistemas técnicos não é único, e nem estes se impõem homogeneamente no espaço: num mesmo território, podem coexistir 
diferentes sistemas técnicos, com ritmos temporais diferentes. Às vezes, um sistema técnico de tempos rápidos torna-se dominante, mas sistemas de tempos lentos podem resistir nos interstícios (SANTOS, 1996). A essas sobrevivências de sistemas técnicos antigos, de tempos lentos, Santos chama rugosidades, conceito que lembra as cultural relicts de Sauer (2002). Como vimos na introdução teórica deste trabalho, mapear e entender a dinâmica de tais rugosidades — um trabalho que Santos compara ao do arqueólogo — pode ser um passo metodológico eficaz na compreensão de sistemas técnicos dominantes em outras épocas.

A abordagem que propomos para o nosso objeto de estudo - a região do Triângulo Mineiro entre os séculos XVIII e XIX, período em que foi ocupada pela sociedade luso-brasileira colonial, e em que se extinguiram as sociedades ameríndias que a antecederam - passa, como vimos afirmando desde o início deste texto, pela categoria da espacialidade - a forma particular, historicamente produzida, com que cada sociedade produz espaço. Entender essas espacialidades consiste, principalmente, em entender a lógica do conjunto de objetos técnicos que essas sociedades produziram. Como Santos, acreditamos que tais objetos técnicos — que em conjunto formam os sistemas técnicos — são a cristalização da História. Por isso, entender sua gênese, difusão e lógica é etapa essencial ao estudo da formação histórica da região.

Neste capítulo, propomo-nos a compreender a gênese e a dinâmica de algumas das técnicas usadas pelos colonos do Triângulo Mineiro, na primeira metade do século XIX, principalmente aquelas ligadas à reprodução cotidiana de suas existências. Usamos três fontes nessa reconstituição: os relatos dos viajantes joaninos, as descrições dos objetos técnicos constantes nos inventários post mortem da vila de Uberaba entre 1822 e 1861, e depoimentos de antigos moradores da região. Esses depoimentos foram coletados num esforço de mapear as rugosidades — isto é, sobrevivências, até tempos recentes, de complexos técnicos antigos — que pudessem nos revelar a lógica do sistema técnico produzido pelos geralistas no século XIX, no Triângulo Mineiro.

Os imigrantes geralistas colonizaram a região do Triângulo dispondo de um sistema técnico engendrado na região central de Minas, ao longo do século XVIII. Teve, contudo, de sofrer adaptações ao ambiente do Cerrado, algo distinto das montanhas mineiras onde surgiu.

A região aurífero-metalúrgica de Minas Gerais, descoberta e colonizada em seus primórdios por paulistas de São Paulo e Taubaté, recebeu 
posteriormente um intenso afluxo de imigrantes baianos, pernambucanos, cariocas, portugueses e açorianos. Simultaneamente, centenas de milhares de escravos africanos foram traficados para a região e, além deles, um grande número de índios foi aldeado e escravizado, desde os tempos dos paulistas.

Esse melting pot de influências gerou uma cultura que herdou técnicas de todos esses grupos. Estes, ao oferecerem uma gama variada de opções, advindas de culturas distintas, deram ampla flexibilidade às formas de exploração daquele ambiente de floresta e campos sobre montanhas. Esse "pacote" de técnicas, assim geradas, foi usado posteriormente na instalação de uma economia agropastoril na comarca do Rio das Mortes, na segunda metade do século XVIII, e no início do século XIX, no Alto Paranaíba e Triângulo Mineiro.

Nessas duas últimas regiões, porém, os mineiros tiveram que adaptar essas técnicas ao ambiente do Cerrado. Nele, a presença de pastagens naturais favoreceu uma pecuária de corte de produtividade expressiva para os padrões da época, mas cujo excedente era difícil de ser escoado. Falaremos a seguir dos complexos técnicos da pecuária bovina e dos principais cultivos — com os respectivos processamentos — desenvolvidos no Triângulo Mineiro, na primeira metade do século XIX.

\section{Terras de cultura e campos de criar}

Ao trazerem a descrição das fazendas, os inventários post mortem do termo de Uberaba, escritos entre 1822 e 1861, sempre se referiam às terras ou matas de cultura e aos campos de criar. Da extensão total de cada fazenda arrolada, aquelas sempre correspondiam a áreas muito menores do que estes, e eram avaliadas por preços bem mais altos. Por exemplo, no inventário de Francisca Cândida de Jesus, sua Fazenda da Saudade foi descrita como

uma parte de terras de cultura e campos de criar que foram vistas e avaliadas por cinquenta e cinco alqueires de plantas de cultura e os matos avaliados a dezessete mil réis cada alqueire de planta, e os campos em duzentos e cinquenta alqueires de planta, avaliados a mil e quinhentos réis o alqueire. ${ }^{1}$

\footnotetext{
${ }^{1}$ APU, inventário de Francisca Cândida de Jesus (25/05/1831), maço N73.
} 
Esses termos designavam, genericamente, fitofisionomias do domínio do Cerrado —- naturais ou secundárias à intervenção antrópica — , vistas segundo seu potencial de aproveitamento pelos roceiros e fazendeiros.

As terras de cultura eram assim chamadas por serem as mais apropriadas aos cultivos de subsistência, por causa da sua fertilidade natural. Correspondiam aos solos de matas, e a presença nelas de algumas espécies vegetais arbóreas revelava sua qualidade. Saint Hilaire referiu-se a essa forma de reconhecimento dos solos: "a experiência ensinou aos brasileiros quais as espécies de árvores comuns nas matas que, preparadas para as culturas, dão colheitas mais lucrativas" (2000). Averiguamos, por meio de depoimentos de antigos moradores da região em estudo, quais eram as espécies de árvores que, uma vez encontradas, mostravam a presença de terras de cultura: “jatobá de cultura (diferente do jatobá de cerrado), ipê amarelo, ipê roxo, bálsamo e peroba rosa”, disse-nos Hélio Rodrigues da Cunha, morador da zona rural de Santa Maria desde os anos $1910 .^{2}$

Tais árvores são encontradas em matas mesofíticas e em matas ciliares, duas fitofisionomias do Cerrado freqüentemente associadas a solos de alta e média fertilidade (RIBEIRO; WALTER, 1998). Portanto, as terras de cultura correspondiam, geralmente, a solos desenvolvidos sobre rochas básicas, como a terra roxa, cambissolos, e latossolos roxo e vermelho-escuro (RIBEIRO; WALTER, 1998).

Nos inventários pesquisados, as terras de cultura usualmente eram referidas pelas fitofisionomias que as cobria, como matas de cultura, capões de mato ou matas virgens, ou - caso se tratassem de matas secundárias - como capoeiras. Por exemplo, José Luís Pereira possuía, em 1841, "quinze alqueires de cultura em capoeira e poucas matas, cercados de valos, e sete e meio alqueires de cultura com capoeiras na margem do córrego denominado Simões". 3 O capitão Mário Bernardes Ferreira tinha "trinta e oito alqueires de Goiás de mato tapado". 4

As terras de cultura com capoeiras, por já terem perdido parte da fertilidade original, eram menos valorizadas que os solos de matas. Por exemplo, no inventário de José Luís Pereira de Sá, já citado, seus sete e meio alqueires de cultura com capoeiras valiam 45 mil réis (ou seis mil réis o alqueire) em 1841.

\footnotetext{
Hélio Rodrigues da Cunha, depoimento gravado, (15/01/2002).

APU, inventário de José Luís Pereira de Sá (21/06/1841), maço N10.

APU, inventário de capitão Mário Bernardes Ferreira (08/11/1845), maço M94.
} 
Já no inventário de Custódio Gonçalves Beirigo, ${ }^{5}$ do mesmo ano, "noventa e sete alqueires de matas" foram avaliados "à razão de dez mil réis o alqueire".

Os campos de criar, referidos nos inventários, correspondiam às áreas usadas - como o nome indica — para o pastejo do rebanho bovino, cavalar e ovino. Nesse caso, tratava-se, na maioria das vezes, de áreas de campos sujo ou limpo, campo cerrado ou mesmo o cerrado strictu sensu mais ralo, onde predominavam latossolos distróficos e álicos, pouco férteis (RiBEIRO; WALTER, 1998). Na região em estudo, tais fisionomias distinguiam-se sobre os chapadões areníticos (REATTO, CORREA; SPERA, 1998), principalmente naqueles localizados entre o rio Uberaba e o rio das Velhas (Feltran, 1997). Quando de sua morte, em 1842, o fazendeiro Manuel Pereira da Silva, por exemplo, possuía "uma sorte de campos no chapadão"; "Francisco Alves Carrejo possuía "duzentos e noventa e sete alqueires de campos no chapadão, à margem do rio das Velhas". 7

Também era comum formarem-se campos secundários, que resultavam, ao cabo de alguns anos, da prática de cultivos de pousio arbustivo sobre terras de cultura. Nos inventários, esses campos eram referidos junto às terras de cultura, já que se desenvolviam a partir destas. Por exemplo, no inventário de Albano Pereira Valle (1846), suas terras foram descritas como "doze alqueires de culturas com campos na fazenda Felicidade" (grifo nosso). ${ }^{8}$

Tais campos secundários originavam-se da deterioração de solos férteis. Os cultivos com pousio arbustivo — de quatro a cinco anos — , quando repetidos várias vezes sobre os mesmos solos, impediam a reconstituição da mata secundária (capoeira ou capoeirão), e a área terminava sendo invadida por ervas alienígenas, como o capim meloso e o capim Jaraguá. Saint Hilaire assim descreveu a formação desses campos secundários:

Quando já se fizeram duas colheitas em um solo outrora coberto de matas virgens, deixa-se o terreno repousar um pouco; brotam aí árvores muito mais delgadas que as primeiras [...]. Deixam-se estas crescer durante cinco, seis ou sete anos, segundo as regiões; cortam-se, novamente, queimam-se em seguida, e faz-se a plantação nas cinzas [...] Quando [na província de Minas Gerais]

\footnotetext{
5 APU, inventário de Custódio Gonçalves Beirigo (03/07/1841), maço N28, caixa 463. APU, inventário de Manuel Pereira da Silva (08/11/1842), maço N 156.

APU, inventário de Ana Joaquina de Jesus (12/06/1844), maço N8.

8 APU, inventário de Albano Pereira Vale (12/04/1846), maço N1.
} 
um terreno já foi cultivado umas poucas vezes, vê-se nascer uma samambaia imensa do gênero Pteris. Uma gramínea viscosa, pardacenta e fétida, denominada capim-gordura, sucede em breve a essa criptógama, ou se desenvolve ao mesmo tempo que ela. Então, quase todas as outras plantas desaparecem com rapidez. Se algum arbusto nasce de permeio ao capim gordura, é logo comido pelo gado e a ambiciosa gramínea fica senhora do terreno (2000, p. 90-91).

Os depoimentos que recolhemos confirmam que, na região em estudo, tais práticas - cultivos em sistema de pousio arbustivo, culminando com a formação de campos antrópicos, onde predominavam gramíneas alienígenas - sobreviveram até tempos recentes. Um morador da zona rural de Patos de Minas (Alto Paranaíba), nos anos 1940, relata que

as pastagens eram naturais, formadas, nas regiões baixas e de terras de cultura, pelo capim Jaraguá, conhecido também por capim provisório, devido à sua efemeridade. Brotava em setembro, no início das chuvas, e mantinha-se verdejante até o final do outono, quando apareciam os primeiros sinais do sol e frio [...]. Nas encostas, predominava o capim meloso ou gordura. ${ }^{9}$

Em Santa Maria (região do médio rio Tejuco), o depoimento de outro morador confirma que, nos anos 1920, as formações de campos antrópicos sobre terras desgastadas de mata eram usadas como pastagens:

A terra agüentava plantar quatro a cinco anos. Depois o povo largava porque tinha mais mata e valia mais a pena, e plantava mais [...]. Nas [terras de] cultura que eram invernadas, onde eram os matos que a gente fazia as roças, a gente semeava as sementes de Jaraguá. Jaraguá e [capim] gordura. Eram só esses dois capins que tinha naquela época para a cultura. Para plantar a gente semeava. ${ }^{10}$

Warren Dean (1996), em sua história ecológica das matas brasileiras, afirma que a prática do pastejo bovino sobre áreas deterioradas de mata surgiu nos séculos XVIII e XIX, no Rio de Janeiro, Minas Gerais e São Paulo. Os capins africanos Jaraguá e meloso (capim gordura), que freqüentemente

9 Geraldo Lourenço Castro, depoimento escrito (02/05/2002).

10 Hélio Rodrigues da Cunha, depoimento gravado (15/01/2002). 
invadiam essas áreas, apareceram, pela primeira vez, nas invernadas próximas ao Rio de Janeiro, em alguma data incerta do século XVIII. Provavelmente trazidos pelos tumbeiros, onde eram usados como cama de palha para os escravos traficados, esses capins se espalharam rapidamente pela capitania de Minas Gerais (DEAn, 1996). Ao tempo de Saint Hilaire, que viajou pela região em estudo em 1819, o capim gordura já havia chegado às nascentes do rio São Francisco, mas ainda não ao Alto Paranaíba:

O capim-gordura, infelizmente tão comum a leste da Serra do Espinhaço, quase nunca ultrapassa a vertente ocidental dessa cadeia, mas aparece com abundância a leste da outra cadeia que limita a bacia do São Francisco, e finalmente deixa de ser visto a oeste da parte meridional desta última cadeia (SAINT HILAIRE, 1975 b, p. 121).

Esses capins foram disseminados pelo próprio gado, segundo Dean (1996). Os criadores reconheciam que essas espécies tinham baixo valor nutricional para as criações. Saint Hilaire comentou que o capim gordura "se por um lado engorda os animais cargueiros e o gado, diminui-lhes sensivelmente as forças" (2000, p. 91). Esse juízo era o mesmo dos moradores que tivemos a oportunidade de entrevistar, e Dean (1996) confirma que ele era verdadeiro: os capins africanos — particularmente o gordura — reduziam a biodiversidade representada pelas diversas espécies de capins nativos, e assim impediam um regime balanceado de aminoácidos e micronutrientes para os rebanhos. $\mathrm{O}$ Jaraguá era tido como um capim mais nutritivo, mas só crescia em terras de cultura e secava logo depois do fim da estação das chuvas. ${ }^{11}$

Os capins nativos eram melhores que os invasores, mas só podiam ser consumidos logo após as queimadas, quando os brotos novos eram mais palatáveis ao gado (DEAN, 1996). Cresciam normalmente sobre os chapadões, compondo a flora nativa dos campos cerrados, campos limpos e campos sujos, como as espécies capim mimoso, capim branco e capim flecha (BACELAR; Brioschi, 1999). Saint Hilaire (1975 a, 1975 b) citou o capim flecha como o preferido pelos criadores de seu tempo, na região em estudo.

A técnica de queimada dos campos do Cerrado, para o manejo de pastagens, foi descrita por Saint Hilaire, nos arredores de Paracatu:

11 Geraldo Lourenço Castro, depoimento escrito (02/05/2002). 
Os pastos nos arredores de Paracatu só são queimados nos meses de julho e agosto, isto é, durante a estação da seca, pois o fogo não se alastra neles quando ateado antes dessa época. Entretanto, quando os fazendeiros desejam ter pastos de capim novo mais cedo, para suas vacas leiteiras, eles reservam uma certa extensão deles, deixando de atear fogo durante um ano inteiro, para no ano seguinte poderem queimá-los nos meses de abril ou maio (1975 b, p. 152).

O pastejo sem pousio sobre os campos, nos chapadões, também levava à deterioração dos solos e da flora nativa, num processo análogo ao das matas. A necessidade de realizar queimadas todos os anos era o principal fator responsável pelo impacto ambiental dessa prática. Dean resumiu os efeitos ecológicos das técnicas de pastejo, correntes nos século XVIII e XIX, na região do Cerrado:

A queimada danifica de modo sutil os solos e o capim. Destrói plantas que se disseminam horizontalmente formando esteiras, em favor das que formam touceiras, expondo o solo e provocando erosão. $O$ fogo reduz a permeabilidade do solo, favorecendo plantas de raízes superficiais, menos eficientes na reciclagem de minerais lixiviados e mais rapidamente ressequidos e não comestíveis na estação seca. A saúva invade quando esses solos secam, promovendo a ingrata tarefa de revolver sua matéria orgânica. A queimada, além do mais, elimina nitrogênio e as bactérias que participam de sua fixação no solo, essencial à nutrição animal. O pasto degradado então se enche de filicíneas, como o capim sapé [...] e com o barba-de-bode, outra gramínea sem valor nutritivo [...] (1996, p. 129).

Nos depoimentos que colhemos, pudemos notar que diferentes situações ambientais levaram a diferentes níveis de valorização dos campos naturais do Cerrado. Áreas possivelmente degradadas, cobertas por barba-de-bode, eram usadas só como último recurso na alimentação do gado. ${ }^{12}$ Já nas regiões onde ainda se encontravam capins nativos mais nutritivos, as pastagens naturais eram mais valorizadas:

12 Geraldo Lourenço Castro, depoimento escrito (02/05/2002). 
Do cerrado o melhor era o capim branco. Ele era meio peludinho. $\mathrm{O}$ cerrado dava mais pasto era no tempo de queimada, na seca o pasto secava muito, aí punha fogo, aí vinham aqueles brotos novos. O gado engordava, ficava bonito, comendo o broto novo. ${ }^{13}$

Para entender a forma como ocorreu a valorização dos campos de criação e das terras de cultura na região e no período em estudo, separamos 34 inventários post mortem, que continham dados mais completos sobre as extensões - medidas em alqueires mineiros ${ }^{14}$ — e preços relativos de ambos, nas fazendas inventariadas no termo da vila de Uberaba, entre 1822 e $1841 . .^{15}$

Os campos correspondiam, em média, a extensões 7,75 vezes maiores que as terras de cultura, em cada fazenda. Isso demonstra que a fazenda típica era formada por extensões relativamente vastas de campos, com algumas áreas de matas ou solos de matas, usados nos cultivos de subsistência.

Havia diferenças, contudo, entre as propriedades maiores e menores que 500 alqueires. As menores tinham uma proporção relativamente maior de terras de cultura: em média, os campos superavam-nas em 5 vezes a sua área. Já as propriedades maiores do que 500 alqueires eram-no principalmente por causa dos campos (de cultura ou de chapadão): nelas, a extensão das pastagens superava, em média, 17 vezes as terras de cultura. Isso demonstra que as terras de cultura, essenciais à agricultura de autoconsumo, eram as mais procuradas pelos pequenos proprietários, para quem os rebanhos, pouco numerosos, podiam ser mantidos em pastagens pequenas. Para quem possuía rebanhos maiores, criando-os para venda ou invernados, as áreas de pastagens tinham que ser muito extensas, por causa do caráter superextensivo da pecuária.

Em função da grande importância dos solos de mata na produção de alimentos em sistema familiar (ou familiar com escravos), à medida que aumentava a densidade demográfica, ao longo da primeira metade do século XIX, subia o preço do alqueire das terras de cultura, no termo de Uberaba. Mas o preço do alqueire de campos aumentou num ritmo muito mais lento no mesmo período, como se vê no gráfico 1. Isso pode ser explicado pela baixíssima densidade de rebanhos sobre os imensos chapadões cobertos por campos naturais, usados como pastagens. O crescimento do rebanho bovino

13 Hélio Rodrigues da Cunha, depoimento gravado (15/01/2002).

14 Um alqueire mineiro ou goiano corresponde a $48.400 \mathrm{~m} 2$, ou 4,8 hectares.

15 APU, inventários post mortem (1822-1861). 
regional e do aproveitamento dos chapadões, até 1861, não foi suficiente para pressionar o preço das terras de campos, o mesmo não acontecendo com as terras de cultura. Estas tiveram seu preço aquecido pelo aumento da demanda por elas, tanto dos pequenos quanto dos grandes agricultores.

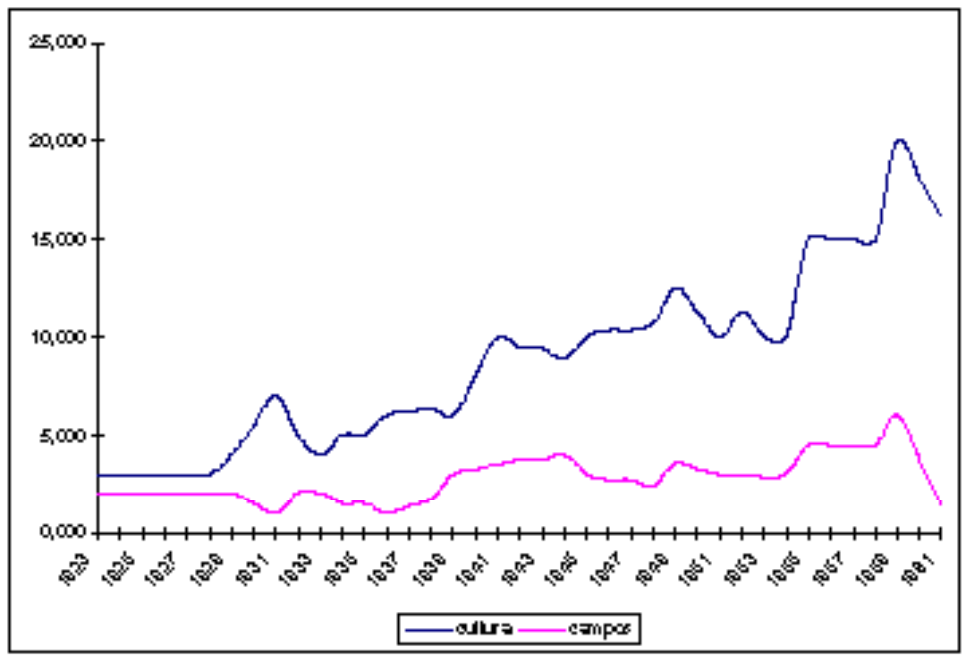

Gráfico 1: preço do alqueire da terra de cultura e dos campos no termo de Uberaba entre 1822 e 1861 (em réis).

Fonte: 174 inventários do Juizado de Órfãos de Uberaba (1822-1861).

Os viajantes joaninos já se impressionavam com o modo extensivo da pecuária dos sertões do Oeste Mineiro. Em 1816, Eschwege comentou, no Araxá, que "a criação de gado, embora em estado semi-selvagem, já rende lucro, sem muito trabalho. O gado é apascentado em campos abertos, em plena liberdade” (1996, p. 107). Dois anos depois dele, Saint Hilaire descreveu a pecuária extensiva araxaense:

Como em todos os lugares, ali só se planta nos capões, ficando os campos reservados exclusivamente aos rebanhos [...]. As fazendas são geralmente de grande extensão, e não é raro encontrar algumas com 9 a 10 léguas de comprimento. Todavia [...] raros são os que contam com rebanhos de mil cabeças, e os que possuem oito ou dez escravos já são considerados ricos (1975 b, p. 130-131). 
Podemos estimar o nível de utilização média das pastagens dividindose a extensão total de campos pela soma de cabeças dos rebanhos, naquela amostra de 34 inventários que destacamos anteriormente. Chegamos ao número de uma cabeça para cada 20 alqueires, ou 97 hectares. Esse número é muito mais baixo que o estimado por Saint Hilaire (1975 b) para a pecuária do Alto Rio Grande, na comarca do Rio das Mortes (uma cabeça por 1,4 hectare), ou do estimado por Dean (1996) para a média da pecuária dos sertões brasileiros (uma cabeça por 5 hectares).

Esse caráter superextensivo da pecuária, mesmo se comparado com outras regiões mineiras da mesma época, como a comarca do Rio das Mortes, devia-se a dois fatores:

- A especificidade da fronteira. O caráter disperso e rarefeito da ocupação fazia com que as fazendas fossem muito grandes, devido ao baixo valor da terra e à existência de extensões devolutas. Com efeito, no mapa demográfico de Luís Maria Pinto, de 1821, a densidade demográfica da comarca do Rio das Mortes era de 64,7 habitantes por légua quadrada $\left(1,4 \mathrm{hab} / \mathrm{km}^{2}\right)$, enquanto que, na de Paracatu, era de 7,3 habitantes por légua quadrada $\left(0,16 \mathrm{hab} / \mathrm{km}^{2}\right)$ (Cunha Matos, 1981).

- O aproveitamento das pastagens naturais. Pelo fato de as espécies herbáceas aproveitáveis no apascentamento se acharem dispersas no terreno, eram necessárias grandes extensões para se obter uma área útil de pastagens relativamente pequena.

A baixa densidade dos rebanhos nas fazendas de gado pôde ser avaliada qualitativamente pela leitura dos inventários post mortem: Antônio da Silveira, ${ }^{16}$ que em 1829 era dono da Fazenda Veríssimo, com extensão de uma légua de comprido por meia légua de largo, com 200 alqueires de campos, possuía apenas 38 cabeças de gado, 6 cavalos e 6 carneiros, o que equivale a cinco alqueires por cabeça, ou uma cabeça para cada 24 hectares.

Os solos de matas eram preparados para o cultivo da mesma forma que nas demais regiões da capitania de Minas Gerais. A derrubada da mata era feita com machado, pouco depois da estação das chuvas. Após alguns dias,

16 APU, inventário de Maria Rodrigues de Jesus (04/04/1829), maço N48, caixa 459. 
com a secagem da rama, ateava-se fogo antes da próxima estação de chuvas (figura 1). No meio da madeira carbonizada, os roceiros abriam covas dispostas irregularmente, usando a enxada, onde então eram lançadas as sementes (SAINT Hilaire, 2000). Nos inventários post mortem pesquisados, os únicos instrumentos agrícolas arrolados em todos os inventários eram enxadas, machados, foices e facões — sendo notável a absoluta ausência de arados — confirmando que esse era realmente o sistema, até 1861, na região em estudo.

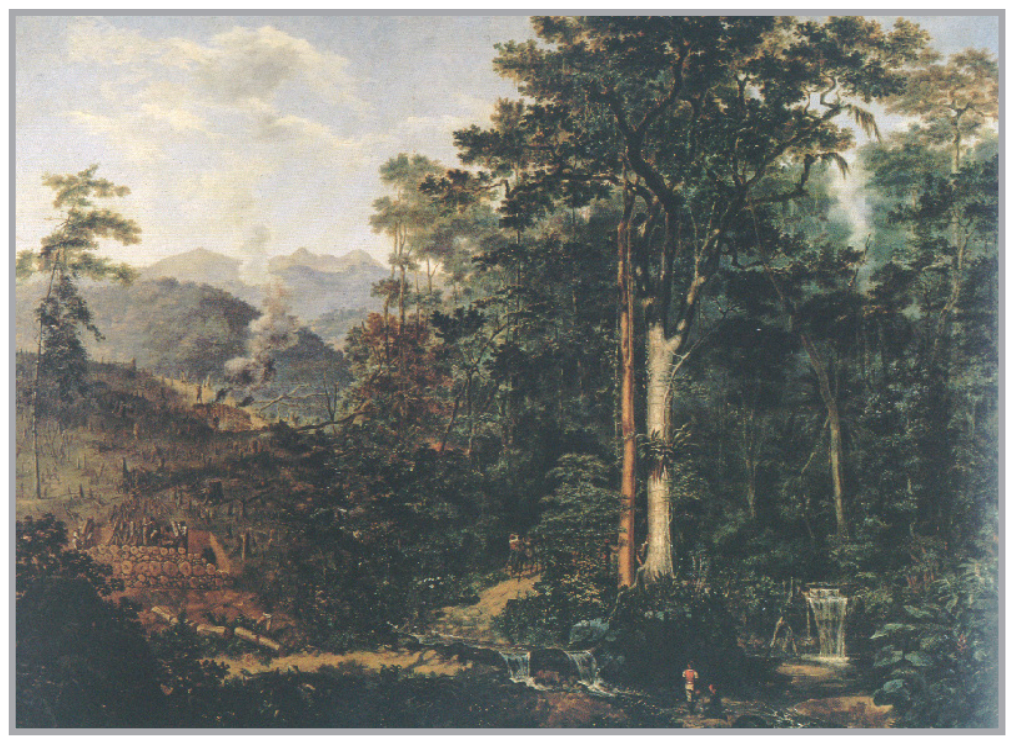

Figura 1: Taunay: mata reduzida a carvão.

Fonte: Beluzzo (1999).

Essa técnica foi chamada, nos depoimentos que coletamos, de roça de toco. Tratava-se, na verdade, da técnica indígena de preparo da terra e cultivo, um pouco modificada, como vimos no segundo capítulo deste trabalho. Essas modificações consistiram, basicamente, no uso do machado de ferro e da foice na derrubada (aumentado a extensão da área abatida, em comparação com a técnica indígena), no uso da enxada na abertura das covas, em vez do chuço, e no encurtamento do tempo de pousio, substituindo o sistema florestal indígena (20 anos) pelo sistema arbustivo sertanejo (5 a 6 anos).

Não foi só nesse caso que as técnicas indígenas foram incorporadas 
ao sistema sertanejo luso-brasileiro, ao longo da colonização. Como veremos, além do sistema de preparo da terra, também no caso das técnicas de cultivo, armazenamento de colheitas e beneficiamento, houve absorção — com adaptações - dos complexos técnicos nativos. Na maioria das vezes, isto se fez porque estes eram vantajosos, mais bem adaptados ao ambiente tropical do que os equivalentes ibéricos. Diante das escolhas postas aos colonos, estes foram adotando as técnicas que sabiam funcionar, observando os indígenas ou aprendendo com os escravos índios e, muitas vezes, depois de testar e abandonar, por inadequadas, aquelas trazidas da metrópole.

No caso que estamos analisando, a tentativa de introdução do arado em terras paulistas é exemplar. Em 1766, o governador de São Paulo morgado de Mateus, escreveu ao vice-rei do Brasil justificando o abandono do uso do arado em favor da cavadeira de pau ou chuço naquela província. Em sua carta, diz que "a terra é fria e não dá sustância senão na superfície, que se não pode usar arado, que alguns já usaram dele, que tudo se lhes perdeu”. O remédio adequado, segundo o governador, seria "um arado que só risque a superfície" (Holanda, 1995, p. 205).

Nos casos que selecionamos a seguir, veremos como os complexos técnicos da pecuária, cultivos e beneficiamento agrícola foram sendo criados historicamente, e adaptaram-se ao ambiente do Cerrado - particularmente no Triângulo Mineiro — nos primeiros anos do século XIX.

\section{Currais, boiadas e sal}

As fazendas de gado foram a principal forma pela qual os colonos geralistas se estabeleceram no Triângulo Mineiro, nos primeiros anos do século XIX. A denominação mais apropriada para essas unidades rurais pioneiras talvez fosse fazendas agropecuárias, já que eram bastante diversificadas. Porém, enquanto cultivos como feijão e milho se destinavam principalmente ao autoconsumo, a pecuária era a principal forma assumida pelo trabalho excedente (mas não a única, conforme se verá), tendo seu valor realizado pela venda de rebanhos em Formiga e São João Del Rey, destinados ao abastecimento do Rio de Janeiro.

No Extremo Oeste Mineiro, Saint Hilaire (1975 a, 1975 b) referiu-se freqüentemente à rusticidade dos criadores de gado, que, não obstante, muitas vezes, 
eram proprietários de imensas extensões fundiárias. De fato, é notável a simplicidade das instalações e dos equipamentos técnicos, nos inventários post mortem da época. Ao morrer, em maio de 1850, Antônio Francisco de Assis possuía um rebanho de 83 cabeças de gado, formado sobretudo por vacas paridas e solteiras, em uma pequena fazenda próxima ao córrego do Lajeado, nos arredores de Uberaba. Era provavelmente jovem, pois tinha apenas duas filhas pequenas — Severiana, de dois anos, e Maria, de três anos — e sua esposa Jesuína estava grávida de um terceiro filho. Contava com um escravo de dez anos, Domingos, e seis cavalos adultos para ajudá-lo no trabalho diário. Vivia em uma casa de taipa coberta de capim, em cujas proximidades funcionava um monjolo. Sua esposa, com o auxílio da escravinha Eva, descaroçava, cardava e fiava algodão, usando um par de cardas e duas rodas de fiar. Também tecia, provavelmente para uso da família, com um tear de madeira. O equipamento técnico com que contavam Antônio e Domingos era formado apenas por um carro com três cangas arreadas (para o qual dispunha de quatro bois carreiros), duas foices, um serrote, uma enxó, um formão, três enxadas, dois machados e uma cavadeira. ${ }^{17}$

O mundo de Antônio é representativo da ampla maioria das unidades rurais do Triângulo Mineiro de então: produção dependente de forma quase integral da força de trabalho humana e da tração animal, baixo investimento na aquisição de bens de capital e subordinação total das atividades agrícolas e de pastoreio à disponibilidade de recursos naturais. No caso da pecuária, o equipamento técnico permanente resumia-se aos currais de aroeira, aos cochos de sal e aos animais de montaria. A simplicidade dessa prática foi registrada pelos viajantes, como o Barão de Eschwege. Referindo-se à região de Araxá e Patrocínio, o mineralogista alemão relatou que "a criação de gado, embora em estado semi-selvagem, já rende lucro [...]. O serviço de dois a três homens, nessas condições, é o bastante para o manejo e a condução do rebanho aos bebedouros" (1986, p. 107).

O investimento em bens de capital, por isso, era muito baixo ou praticamente inexistente. Gorender (1988) acredita que o baixo nível técnico da economia colonial devia-se à rigidez do sistema escravista, incapaz de gerar ou absorver inovações. No caso em estudo, além disso, a baixa receptividade a inovações explicava-se também pela facilidade com que os recursos naturais

17 APU, Inventário de Antônio Francisco de Assis (04/05/1850), maço N14, caixa 470. 
eram obtidos e manipulados, em fronteira aberta, o que desestimulava sua otimização e os aumentos de produtividade. Gorender chamou a atenção para o baixo custo da implantação de uma fazenda de gado mineira, devido ao fácil acesso à terra (principalmente em regiões de fronteira) e à existência de pastagens naturais:

Sob o prisma econômico, chama logo a atenção a pequenez do fundo inicial exigido pela pecuária em comparação com o engenho de açúcar. A rigor, o fundo inicial se resumia em certo número de cabeças de gado para a criação e de cavalos, que servirão de animais de trabalho. Uma fazenda pequena, informa um observador de começos do século XIX, principia com 200 ou 300 reses, bastando-lhe 25 a 30 cavalos. [...] As instalações, por sua vez, são extremamente sumárias: residências sumárias e currais que se constroem sem muita dificuldade. As pastagens naturais dispensam preparação, quando muito precisam ser periodicamente queimadas a fim de revigorarem. [...] A mão de obra na fazenda é reduzida: grandes fazendas não carecem mais que 15 ou 20 homens de trabalho (GORENDER, 1988, p. 426).

A pecuária do Extremo Oeste Mineiro da primeira metade do século XIX baseava-se em práticas algo diferentes das de duas outras regiões de Minas, na mesma época: o Sertão ou Deserto do rio São Francisco, ${ }^{18}$ e a comarca do Rio das Mortes. Não tão extensiva como a primeira, porém menos intensiva que a última, parece ter sido o resultado da adaptação das técnicas desenvolvidas na região aurífera e no Sul de Minas, ao longo do século XVIII, ao ambiente do Cerrado do Triângulo Mineiro.

Por certo, tratava-se de uma pecuária completamente diferente daquela desenvolvida na mesma época no Sertão ou Deserto do São Francisco. Ali, as práticas da pecuária sertaneja, descritas por Saint Hilaire, filiavam-se à tradição do Sertão Nordestino. O naturalista francês relatou que, na região de Formiga do Sertão ${ }^{19}$ — em área de transição do Cerrado para o domínio da Caatinga —, as pastagens eram muito extensas, e o gado era criado nelas "passando todo o ano nos campos; não é recolhido a currais, e colonos existem que, só possuindo dois

\footnotetext{
18 Hoje Norte e Noroeste do Estado de Minas Gerais.

19 Hoje Montes Claros.
} 
escravos, têm, no entanto, vários milhares de cabeças de gado" (2000, p. 313).

O uso do trabalho escravo naquelas fazendas era pouco comum: "os vaqueiros são muito comumente os próprios filhos do proprietário, ou então homens livres a quem se dá o terço do produto do rebanho" (p. 314). As imensidões das pastagens faziam com que "muito freqüentemente os currais [estivessem] situados a certa distância das fazendas. Na época em que as vacas e éguas têm crias, os vaqueiros vão estabelecer-se próximo a esses recintos, em uma cabana a que chamam retiro [...]" (p. 314).

Esse sistema era o mesmo adotado na região dos Pastos Bons, entre o Piauí e o Maranhão, no Sertão Nordestino. A única diferença era que, na relação de trabalho entre o fazendeiro e o trabalhador livre, no lugar da terça parte dos novilhos que nasciam, o vaqueiro nordestino obtinha do dono da boiada a quarta parte, ou quarta, com o que ia formando seu próprio rebanho (GORENDER, 1988).

Uma vantagem natural com que contava a pecuária de toda a região do São Francisco, Nordeste e Norte de Minas era a presença das minas de salitre, que supriam as necessidades de sal do rebanho sem que os criadores tivessem que recorrer ao sal marinho importado. No Norte Mineiro, o salitre era extraído em Coração de Jesus e Formiga do Sertão, de onde era vendido a negociantes nos portos fluviais de Salgado ${ }^{20}$ e São Romão, e dali distribuído aos fazendeiros do Sertão e a Paracatu, chegando por essa vila aos criadores goianos (SAint Hilaire, 2000).

O sistema de pecuária que era então praticado na comarca do Rio das Mortes, particularmente no Alto Rio Grande, tinha características bastante diferentes do sistema superextensivo do Sertão do São Francisco. Saint Hilaire esteve, em 1819, na região da vertente ocidental da Serra da Mantiqueira, que corresponde ao atual Sul de Minas. Ali percebeu que, diferentemente do Sertão, "o cuidado dos animais é normalmente confiado a escravos" (1975 b, p. 50). As pastagens eram divididas e aproveitadas de forma mais racional e intensiva, num sistema de rotação:

Na região do Rio Grande, os grandes proprietários costumam dividir em quatro porções as pastagens destinadas às vacas de leite, e de três em três meses põem

20 Hoje Januária. 
fogo numa delas, para renovar o capim. [...] depois de divididas as pastagens em diferentes verdes [...] não se pode alimentar mais do que 600 ou 700 cabeças de gado em cada duas léguas de terra (p. 51).

Outro aspecto peculiar dessa pecuária era a sua maior produtividade em leite, para os padrões da época: em média, quatro litros por vaca por dia, o que corresponde ao dobro do que se produzia no Sertão do São Francisco. A maior parte desse leite era transformada em queijos, que, embarcados em tropas, eram vendidos no Rio de Janeiro (SAINT HiLAIRE, 1975 b).

Os fazendeiros do Alto Rio Grande desciam para a Corte um grande número de boiadas e porcadas (FRAGOSO, 1998). Por causa da maior proximidade geográfica, se comparada com os sertões ocidentais, esse comércio contava com um número menor de intermediários. Por causa disso, é possível que uma maior fração do excedente, gerado nas atividades de criação e fabricação de queijos, fosse retida pelos fazendeiros locais. Com efeito, Saint Hilaire comentou que

é de supor que as fazendas da região do Rio Grande dêem um certo rendimento aos seus proprietários, ao contrário das que, encravadas nos sertões de Goiás ou mesmo em algumas partes mais afastadas da província de Minas, quase nenhum lucro dão aos fazendeiros. A vizinhança com o Rio de Janeiro coloca a região e toda a comarca do Rio das Mortes numa situação bastante favorável.

Essa maior acumulação se refletia na aquisição de escravos e gado. Saint Hilaire refere-se a fazendeiros do Alto Rio Grande com até 5.000 cabeças, sendo que, nos inventários analisados em nossa região de estudo, o proprietário do maior rebanho era o tenente Joaquim da Silva e Oliveira, ${ }^{21}$ com 2.351 cabeças, em 1839.

A pecuária trazida pelos geralistas que imigraram para o Triângulo Mineiro na primeira metade do século XIX, vindos da região aurífera e da comarca do Rio das Mortes, originou-se decerto dessas práticas. Contudo, dois fatores geográficos obrigaram os criadores triangulinos a modificarem algumas delas.

Em primeiro lugar, a maior distância em relação ao Rio de Janeiro condicionava a existência de uma rede de comerciantes de gado, intermediária

21 APU, inventário de tenente Joaquim da Silva e Oliveira (06/03/1839), maço N7, caixa 461. 
entre os criadores e aquele mercado. Os relatos de Eschwege (1996) e Saint Hilaire (1975 a; 1975 b) revelam que, entre os criadores triangulinos e o mercado da Corte, interpunham-se os compradores de gado de São João Del Rei ou Formiga, e os condutores de boiadas de Barbacena ou da própria Corte, que as compravam daqueles. Na prática, isso significava uma maior fração do excedente retido nas mãos de intermediários, o que reduzia o montante acumulado pelos fazendeiros triangulinos. Ao mesmo tempo, escravos e artigos como sal e ferragens, comprados do litoral, chegavam muito mais caros ali do que nas regiões mais próximas do litoral.

O acesso ao sal era uma dificuldade a mais para os criadores da região, e talvez um fator limitante na expansão dos rebanhos. No termo de Uberaba, uma saca de sal de $20 \mathrm{~kg}$ custava $5 \$ 120 \mathrm{em} 1837,{ }^{22}$ enquanto um garrote de quatro anos — e, portanto, em ponto de venda - era avaliado a $8 \$ 000 .{ }^{23}$ De acordo com as informações que colhemos em nossos depoimentos, ${ }^{24} \mathrm{um}$ boi consumia em média $100 \mathrm{~g}$ de sal por mês, ou 1,2 kg por ano. Assim sendo, para manter um rebanho de 100 cabeças, um criador teria que comprar $120 \mathrm{~kg}$, despendendo $30 \$ 720$ por ano. Saint Hilaire informou que uma boiada de 100 cabeças rendia até 10 garrotes por ano: "um fazendeiro não poderia, sem reduzir o seu capital, vender todo ano mais do que um décimo do seu gado" (1975 b, p. 49-50), e assim, em 1837, obteria $80 \$ 000$ de receita bruta, dos quais teria que reservar $30 \$ 700$, ou $37 \%$ do total, na aquisição de sal. Dessa maneira, entende-se a razão do caráter superextensivo da prática da pecuária: a atividade só seria lucrativa se os outros fatores de produção (pastagens, força de trabalho) tivessem custo reduzido.

O custo do sal, em alguns casos, era mitigado pela presença dos bebedouros: fontes naturais de águas salitrosas, usadas pelos fazendeiros para dar de beber ao gado. Vimos que a abundância dessas fontes na região do Araxá e Patrocínio fora o fator que tornara esses núcleos — principalmente Araxá — os principais centros de pecuária do Oeste Mineiro, nos primeiros anos do século XIX.

Se bem que menos abundantes que o Barreiro araxaense, tais bebedouros eram encontrados em outras partes do Triângulo Mineiro, e também nelas sua presença estimulou a ocupação pelas fazendas de gado. Esses bebedouros foram referidos, por exemplo, na região da Rocinha, nas vizinhanças do rio das

22 APU, innçalves Firme (01/02/1837), maço N5.

23 APU, inventário de Antônio da Silveira (19/08/1837), maço N37.

24 Geraldo Lourenço Castro, depoimento escrito (02/05/2002). 
Velhas (Eschwege, 1996; Saint Hilaire, 1975 a); nas paragens de Sobradinho e Bebedouro, entre o rio das Velhas e o Uberaba Legítima (TeixeIRA, 1970); e principalmente nos arredores de Uberaba, devendo ser destacado como um dos fatores que estimulou o crescimento do arraial. De fato, Vigário Silva, referindo-se àquela freguesia, escreveu em 1829:

[...] se vê sempre gordo o gado, que não depende de sal, cuja falta se supre com as águas dos bebedouros, que bá em quase todas as faz̃endas. São estas águas nascidas em olhos à margem dos córregos; no paladar não apresentam diferença das outras, mas esfregando-se nelas as mãos sente-se escorregarem; a cana do mato e mesmo o gado acostumado aos bebedouros as procuram sempre na lua nova, passando por outras muitas águas puras, que desprezam apesar da sede [grifo nosso] (SILVA, 1970, p. 11).

Distâncias tão grandes em relação ao mercado da Corte obviamente impediam que o queijo pudesse ser comercializado pelos criadores do Triângulo Mineiro e Alto Paranaíba. Por isso, não havia interesse em produzi-lo. Eschwege observou que:

De manhã e à tarde, as vacas deixam espontaneamente o pasto pra alimentarem os bezerros e é nessas ocasiões que são ordenhadas. [...] Logo que as crias atingem alguns meses de vida e o fazendeiro não tem maior necessidade de leite — na maioria das fazendas não se fabricam queijos nem manteiga, atividade considerada cansativa -, tanto as vacas quanto as crias são enxotadas para o pasto (1996, p. 107-108).

Desse modo, distintamente dos criadores de gado do Alto Rio Grande, a pecuária do Extremo Oeste realizava excedentes exclusivamente na forma do gado de corte.

Outro fator importante era a diferença geomorfológica entre o ambiente da Serra da Mantiqueira e o das chapadas do Oeste. É muito provável que as desvantagens, devidas à distância em relação aos mercados litorâneos, fossem parcialmente compensadas pela possibilidade de explorar pastagens muito mais extensas do que na comarca do Rio das Mortes. Não só porque o Extremo Oeste Mineiro era menos povoado, mas também porque o relevo de chapadas impunha 
menor desgaste físico ao gado em deslocamentos de longa distância, se comparado aos morros do Sul de Minas. Só assim se explica, por exemplo, a funcionalidade do Barreiro do Araxá, para onde os fazendeiros, todos os meses, num raio de 12 léguas $(79 \mathrm{~km})$, levavam seus rebanhos a fim de se servirem das águas salitrosas.

Era possível aos pecuaristas triangulinos, portanto, explorar extensas áreas de pastagens com rebanhos relativamente pequenos. Se, por um lado, isso acarretava uma densidade menor de cabeças por unidade de área, por outro, reduzia o trabalho necessário ao manejo das pastagens. Saint Hilaire relatou que, no Araxá, “a mão-de-obra é bastante cara [...]. Os criadores vêem-se impossibilitados de cercar seus pastos e dividi-los, conforme a prática adotada no Rio Grande" (1975 b, p. 131).

Assim, os pecuaristas do Triângulo Mineiro e Alto Paranaíba conseguiam compensar, em parte, as desvantagens da distância em relação ao grande mercado consumidor da época - a Corte do Rio de Janeiro e a cafeicultura em expansão no vale do Paraíba do Sul — , reduzindo os custos de implantação e manejo da atividade a níveis elementares. Isto só poderia se dar numa situação em que se pudesse contar com recursos naturais abundantes e facilmente exploráveis, e numa forma de produção não-capitalista, na qual a reprodução da força de trabalho não se fazia pela sua prévia realização no mercado. Discutiremos esse aspecto no capítulo 5.

As distâncias e as extensões das pastagens naturais não eram, contudo, tão grandes como no Sertão do São Francisco. No Triângulo Mineiro, todo o manejo do gado era feito nos currais contíguos à casa de morada, não havendo, como lá, o sistema dos retiros. No Norte Mineiro, como vimos, os vaqueiros deslocavam-se para os pastos mais longínquos na época de parição das vacas. Já na região em estudo, segundo Eschwege,

durante o período que vai de agosto a janeiro, porém, requer-se mais trabalho humano, pois é tempo de parição. Ao darem cria, as vacas são levadas para as proximidades da sede da fazenda, onde ficam encerradas no curral, durante a noite. De manhã e à tarde, as vacas deixam espontaneamente o pasto pra alimentarem os bezerros e é nessas ocasiões que são ordenhadas (1996, p. 107-108)

A necessidade de acompanhar as vacas na parição e mantê-las nos currais, segundo um depoimento que colhemos de um antigo morador da região de 
Patos de Minas, devia-se a

dois motivos: o primeiro porque, se deixasse ela parir no pasto, sozinha, poderia ser vítima de alguma complicação [...], e o segundo, porque se não tivesse ninguém por perto ou se não estivesse fechada no curral, era evidente que ela amoitaria o bezerro que, se não o achassem, não saia do local onde foi posto. ${ }^{25}$

O curral era também o lugar onde era realizada a ordenha da vaca. Ao tempo de Eschwege, a técnica de ordenha era a mesma que se manteve na região até bem recentemente:

De manhã e à tarde, as vacas deixam espontaneamente o pasto para alimentarem os bezerros e é nessas ocasiões que são ordenhadas. Para tanto, espera-se que a cria mame um pouco, para, logo em seguida, ser afastada à força e atada às pernas dianteiras da mãe com corda curta, a fim de que ambas se mantenham quietas. É o momento em que se inicia a ordenha. Sem tais precauções, dizem, a vaca não solta o leite (1996, p. 107).

Esse conjunto de técnicas, tão diferentes daquelas do Sertão do Norte Mineiro, são, todavia, as mesmas descritas por Saint Hilaire (1975 b) para a pecuária do Alto Rio Grande. Os currais, anexos à morada do fazendeiro ou sitiante e construídos em madeira aroeira ou pedra, eram o local onde se fazia o manejo do gado. Essa disposição ainda hoje pode ser vista em antigas fazendas da região (figura 2).

Uma outra característica da pecuária do Rio das Mortes que se manteve no Triângulo Mineiro foi o uso do trabalho familiar, estendido pelo trabalho escravo, como forma predominante de organização do trabalho, conforme teremos oportunidade de demonstrar no próximo capítulo. Isso diferenciava a pecuária triangulina da do Sertão do São Francisco, onde, como vimos, predominava o trabalho livre não-assalariado.

Dessa forma, a pecuária triangulina do século XIX era herdeira das técnicas desenvolvidas na região central e sul da capitania de Minas Gerais, ao longo da segunda metade do século XVIII. No entanto, adaptou-se ao ambiente

25 Geraldo Lourenço Castro, depoimento escrito (02/05/2002). 
de Cerrado e chapadas, e às grandes distâncias em relação ao mercado litorâneo, modificando as técnicas de apascentamento de forma a reduzir ao mínimo os custos de produção, pela máxima exploração dos recursos naturais.

A partir do que expusemos, foi possível mapear as principais formas de pecuária desenvolvidas na província de Minas Gerais, na primeira metade do século XIX, conforme se nota na figura 3. Vimos serem três os tipos de pecuária mineira: a pecuária superextensiva do Sertão do Rio São Francisco, ligada às tradições do Nordeste brasileiro; a pecuária da comarca do Rio das Mortes, semi-intensiva (para os padrões oitocentistas) e leiteira; e a pecuária dos sertões do Oeste Mineiro (destacando-se a região em estudo), mais extensiva que esta última e voltada para a venda exclusiva de rebanhos de corte, mas com práticas herdadas das regiões central e sul de Minas.

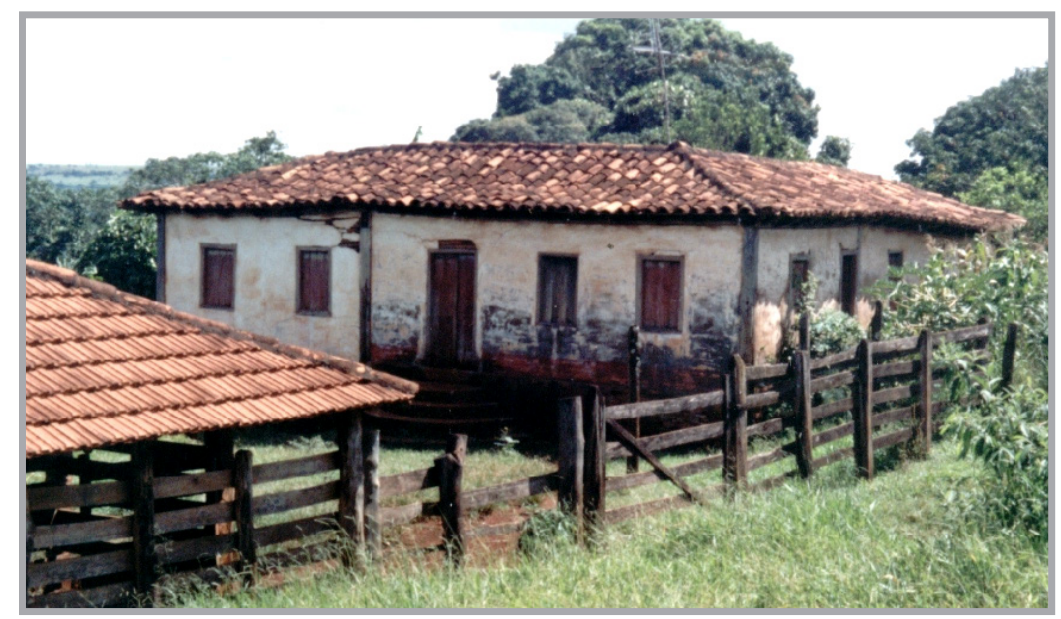

Figura 2: Nova Ponte (MG): casa de fazenda e curral contíguo.

Fonte: foto de Lourenço, L. A. B. (2002).

\section{O milho e a mandioca.}

Sérgio Buarque de Holanda (1995) analisou a difusão do que chamou de civilização do milho, isto é, o conjunto de tradições responsáveis por tornar o milho a principal forma de alimento consumido pelos colonos do Planalto Paulista, no século XVII. Era consumido na forma de farinha pilada — usada para 


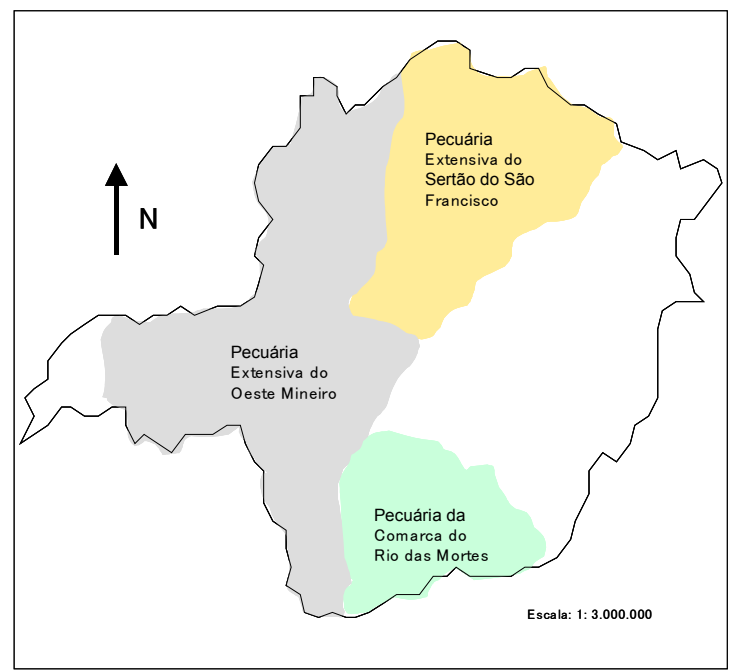

Figura 3: sistemas de pecuária na província de Minas Gerais (1800-1850).

fazer o "pão da terra" —; verde, à moda indígena (cozido ou assado); moído, na forma do fubá, usado para fazer o angu dos escravos; e, seco e debulhado, na alimentação de porcos e galinhas. As técnicas de cultivo e beneficiamento desse grão indígena foram apropriadas quase integralmente dos povos nativos, com exceção da moagem. Esta só surgiu no espaço paulista no século XVIII, com a escravidão negra (HoLANDA, 1995).

O historiador revela que os paulistas, colonos pioneiros das Minas na virada do século XVII para o XVIII, foram os introdutores nessa capitania do complexo do milho. $\mathrm{O}$ uso do milho como principal alimento calórico diferenciava a área sob influência paulista daquela sob influência nordestina, onde a mandioca tomava o lugar do cereal (Holanda, 1995). De fato, Antonil (1982) descreveu em 1711, na vertente ocidental da Serra da Mantiqueira, uma paisagem agrícola tipicamente paulista, onde se nota a presença do milho e a ausência da mandioca:

Aqui há roças de milho, abóboras e feijão, que são as lavouras feitas pelos descobridores das minas e por outros, que por aqui querem voltar. E só disto constam aquelas e outras roças nos caminhos e paragens das minas, e quando muito, têm de mais algumas batatas (ANTONIL, 1982, p. 182-183). 
Um século depois, Saint Hilaire registrou a presença do milho e a falta da mandioca, nos arredores de Vila Rica. Falando do Sertão do São Francisco, relatou que "um vegetal que cultivam muito, e que não se vê nos arredores de Vila Rica, é a mandioca" (2000, p. 311). Nas vizinhanças da capital mineira, por outro lado, "todos os agricultores plantam milho" (p. 106).

O cronista assinalou, inclusive, quando da sua passagem pela região em estudo, uma linha divisória aproximada separando a preferência pelo milho e pela mandioca: "ao norte do Paranaíba começam as plantações de mandioca” (Saint Hilaire, 1975 b, p. 120). Embora não tenha feito uma localização precisa das áreas do grão e do tubérculo, Pohl (1976) só veio descrever os sistemas de cultivo e beneficiamento da mandioca nas proximidades da Serra dos Cristais, ${ }^{26}$ em Goiás, sendo provável que não os tenha visto na sua passagem por Araxá.

Apesar de a carta de frei Leandro, de 1827, referir-se em Uberaba a "mandiocas de cinco a seis meses que tinha maiores raízes que as de seis anos nas Gerais" (PonTes, 1978, p. 91), e Vigário Silva (1970), dois anos depois, citar a mandioca entre os cultivos uberabenses, é possível que o tubérculo não estivesse entre as preferências alimentares da região. Nos inventários pesquisados, produzidos no termo de Uberaba, que corresponde a todo o atual centro-sul do Triângulo Mineiro, é notável a ausência da mandioca e dos equipamentos técnicos usados em seu beneficiamento, entre 1822 e 1861.

Alguns desses documentos traziam a descrição dos estoques de mantimentos em poder do inventariado, quando de sua morte. Dessa forma, pela discriminação e quantificação dos estoques, podemos ter idéia do que se produzia nas fazendas e sítios. Conforme pode ser visto na tabela 1, não houve uma única ocorrência de estoques de mandioca ou farinha de mandioca. Tampouco encontramos, nos arrolamentos dos inventários, qualquer referência ao instrumental usado no beneficiamento da mandioca: raladores, tapiches ou espremedores. É muito provável, portanto, que a porção central e sul da região em estudo - pelo menos até 1861, período a que se referem nossas fontes primárias — não usasse habitualmente a farinha de mandioca.

26 Hoje Cristalina. 


\begin{tabular}{l|cccc}
\hline & \multicolumn{5}{|c}{ NÚMERO DE OCORRÊNCIAS POR PERIODO } \\
\hline GÊNERO & $1822 / 1831$ & $1832 / 1841$ & $1842 / 1851$ & $1852 / 1861$ \\
\hline MILHO & 3 & 3 & 2 & 5 \\
\hline FEIJÃO & 2 & 1 & 1 & 2 \\
\hline ARROZ & - & - & - & 1 \\
\hline ALGOdÃO & - & - & 2 & 1 \\
\hline CANA/AÇÚCAR/ & 1 & 2 & 2 & 3 \\
RAPADURA & - & - & - & 1 \\
\hline FUMO & - & - & - & - \\
\hline MAMONA & - & - & & 1 \\
\hline MANDIOCA & & &
\end{tabular}

Tabela 1: número de ocorrência de estoques de mantimentos nos inventários post mortem no termo de Uberaba, por período (1022-1861).

Fonte: APU, inventários post mortem (1822-1861).

Se dermos crédito à geografização proposta por Saint Hilaire, as áreas de cultivo preferencial do milho e da mandioca, em Minas Gerais, distribuíam-se da forma mostrada no mapa da figura 4 . O botânico francês tentou explicar essa distribuição por fatores de ordem natural. Segundo ele, a presença da mandioca ao norte do Rio Paranaíba "parece provar que a região ali é mais quente e mais elevada, pois essa planta, muito comum na parte do sertão que percorri em 1817, não é encontrada em regiões elevadas e de clima temperado" (1975 b, p. 120).

Holanda, de outro modo, parece julgar que a geografia dos cultivos coloniais se deve muito mais a fatores culturais do que propriamente climáticos ou pedológicos. A mandioca, muito comum na Baixada Santista desde o início da colonização, esteve ausente dos cultivos praticados na vila de São Paulo até 1800. Ali, era o milho que ocupava o lugar de principal fonte de carboidratos para a população do Planalto do Piratininga. A razão, segundo o autor, é que as ramas de mandioca eram muito difíceis de serem transportadas, pois morriam alguns dias depois de arrancadas e ocupavam muito espaço nas bagagens. Assim, como as viagens serra-acima 


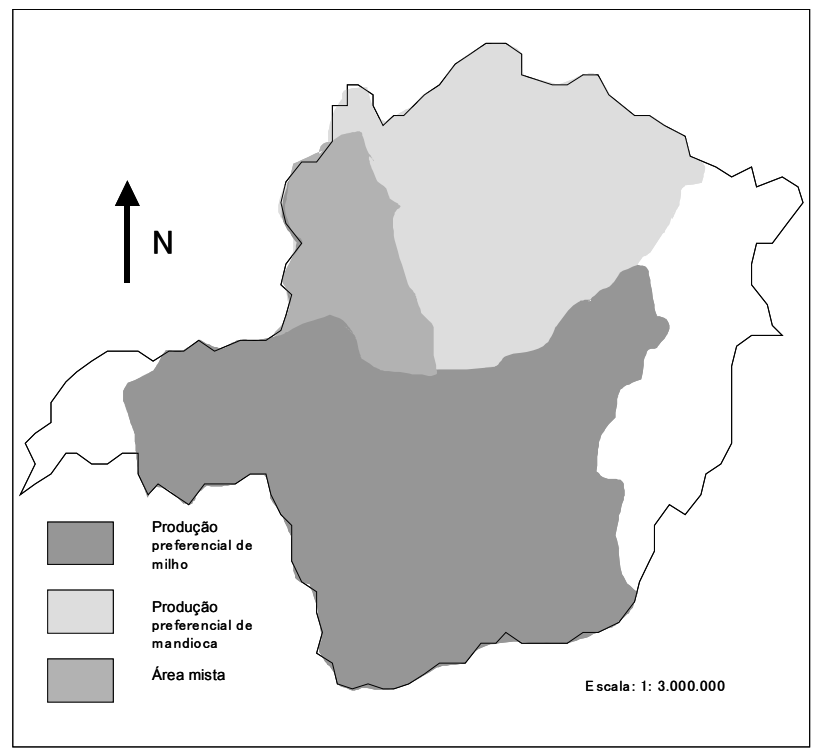

Figura 4: áreas preferenciais de cultivo do milho e da mandioca para alimentação humana (1819). Fonte: Saint Hilaire (2000).

eram relativamente longas, o milho — levado em sementes - é que se transformou no principal alimento. Os colonos só adotavam a mandioca quando, nas áreas a serem colonizadas, já existissem grupos indígenas mandioqueiros (Holanda, 1995).

Outros elementos de ordem cultural também influíram nas preferências regionais pelo tubérculo ou pelo grão. Holanda (1995) escreveu que os paulistas antigos tinham aversão à farinha de mandioca, considerada pouco nutritiva. Já entre os nordestinos e os nortistas, segundo o mesmo autor, o juízo negativo era dirigido contra a farinha de milho. No norte de Minas Gerais, Saint Hilaire destacou o uso da mandioca como alimento preferencial em todo o Sertão ou Deserto do Rio São Francisco. O milho, embora cultivado, era tido como alimento de animais e escravos:

Os sertanejos preferem a raiz da mandioca, porque têm, em geral, a crença de que [...] o milho produz neles moléstias de pele tais como a sarna, a lepra 
e a elefantíase, e aqueles mesmos que o têm em abundância o não empregam senão para a alimentação dos burros, dos porcos e das galinhas (2000, p. 311).

O quadro geográfico que parece se desenhar para o território mineiro oitocentista, em relação ao binômio milho/mandioca, é o da delimitação de duas áreas culturais distintas, uma com o predomínio do complexo da mandioca, e outra com o predomínio do complexo do milho. E é interessante notar que os limites entre tais áreas coincidem aproximadamente com os dos dois sistemas de pecuária de corte, que estudamos linhas atrás. Desse modo, o domínio do complexo da mandioca coincide aproximadamente com o espaço da pecuária superextensiva de tradição nordestina, e a área do milho, com a pecuária escravista que se originou no centro e no sul de Minas. A conclusão que se impõe é que a região em estudo se filiava a uma tradição cultural mineira strictu sensu, enquanto no Médio São Francisco parece clara a influência do Sertão Nordestino.

No entanto, tais preferências rapidamente se interpenetraram na cultura sertaneja triangulina. Pohl (1976) descreveu, em Goiás, bem próximo ao Triângulo Mineiro, a presença tanto de produtos do milho quanto da mandioca, em 1817. No termo de Uberaba, pelo menos até 1861, a mandioca tinha pouco significado na vida sertaneja, mas, em algum momento entre essa data e o final do século XIX, a prática de seu cultivo se intensificou na região. Em depoimento, o agricultor Hélio Rodrigues da Cunha, que vive na região do Médio Rio Tejuco desde a década de 1910, descreveu o preparo da farinha de mandioca quando de sua infância. ${ }^{27}$

Preparamos o quadro 1 para mostrar, por etapas, o cultivo do milho, comparando a técnica indígena descrita por Galvão (1979) usada pelos Kaiuá e os povos do cerrado; a técnica descrita por Saint Hilaire (2000), dos roceiros de Minas em 1819; e aquela empregada pelos moradores da região rural de Patos de Minas em 1945. ${ }^{28}$

Pode-se verificar, no quadro comparativo, que as etapas no cultivo e no preparo do milho são as mesmas, nos três casos. Isso faz supor que o manejo indígena do milho foi incorporado pelos roceiros luso-brasileiros, mantendose praticamente inalterado desde os tempos coloniais até muito recentemente.

27 Hélio Rodrigues da Cunha, depoimento gravado (15/01/2002).

28 Geraldo Lourenço Castro, depoimento escrito (02/05/2002). 
Holanda (1995) já tinha chamado a atenção para esse fato, referindo-se ao complexo do milho no Planalto Paulista:

Tomadas, quase que sem alteração, aos antigos naturais da terra, essas técnicas acomodavam-se mais facilmente à vida andeja e simples de parte notável da população do planalto. Tratando-se, além disso, de gênero cuja produção visava, não ao lucro comercial, mas à subsistência familiar, faltou um estimulo técnico poderoso para o desenvolvimento de recursos técnicos favoráveis à produção em maior escala (1995, p. 188).

O quadro 1 também mostra grande semelhança entre o sistema usado na província de Minas Gerais, descrito por Saint Hilaire, em 1819, e o que ainda era comum entre os sertanejos de Patos de Minas, na década de 1940. Essa semelhança aparece até mesmo em detalhes, como distância entre as covas e época de capina. Comparando-se o sistema sertanejo com o indígena, percebe-se que foi na etapa do beneficiamento, principalmente, que técnicas luso-brasileiras foram incorporadas.

Assim, a associação do plantio do milho ao do feijão, de forma que os talos do primeiro servissem às ramas do segundo - técnica milenar entre os povos ameríndios —, manteve-se como prática na região em estudo. Nos inventários do termo de Uberaba, de 1822 a 1861, encontramos estoques de milho arrolados em treze documentos. Em seis deles, o estoque de milho é descrito junto com o estoque de feijão e, em outros sete, o milho é arrolado isoladamente. Mas não encontramos nenhum registro de estoques isolados de feijão. Isso demonstra que o feijão era sempre colhido — quando plantado — junto com o milho, havendo então a associação entre os cultivos.

O pilão indígena foi mantido, para produzir, do milho seco, a canjica ou farinha de milho (figura 5). Mas a máquina rústica que mais freqüentemente está associada ao complexo do milho é o monjolo (figuras 6 e 7), trazida pelos portugueses e incorporada ao complexo do milho.

Esse maquinário rústico, trazido da Ásia Oriental pelos portugueses, e usado em Portugal no beneficiamento do milhete, foi introduzido na Baixada Santista ainda no século XVI, associado originalmente ao beneficiamento do arroz. Até o século XVIII, não parece ter sido muito utilizado no Planalto Paulista, preferindo-se até então o pilão indígena. Dessa época em diante, porém, o monjolo de pé — que não usa água e sim a força humana — passou a ser 


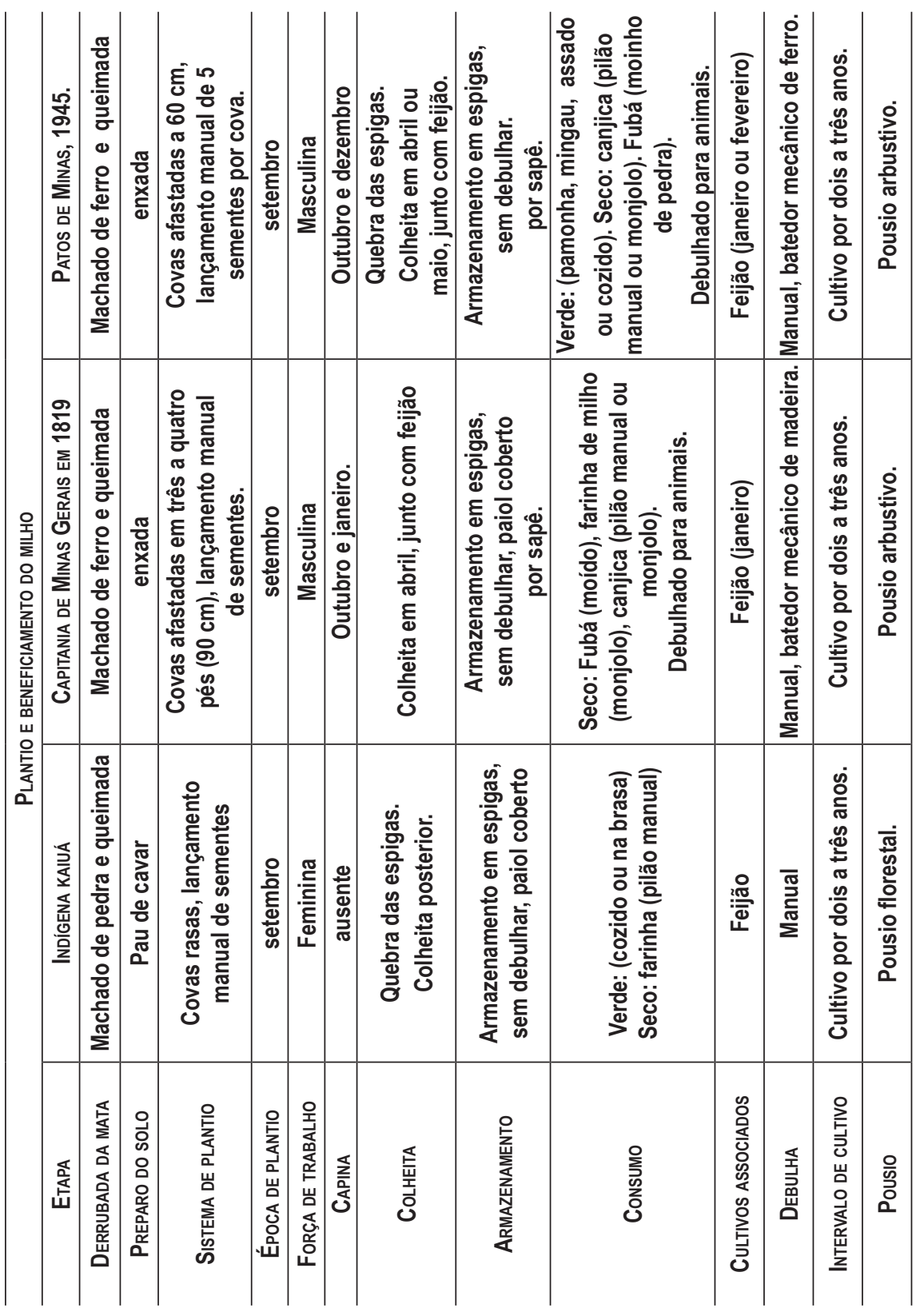

Quadro 1: sistemas de plantio e beneficiamento de milho.

Fontes: Galvão (1979), Saint Hilaire (2000), G. L. Castro, depoimento (2002). 
usado em São Paulo (Holanda, 1995). Algum tempo depois, disseminou-se pelas áreas de colonização paulista, inclusive Minas Gerais, já como monjolo de água, associado ao beneficiamento do milho.

O moinho de pedra, usado para produzir fubá, foi mais um equipamento incorporado ao complexo do milho pelo colonizador europeu. Segundo Holanda, o moinho de fubá incorpora-se ao conjunto das técnicas do milho, no momento em que se torna necessário aumentar a escala do beneficiamento do grão, para "forjar um tipo de alimentação abundante, boa para escravos e criações domésticas" (1995, p. 188). Outros equipamentos que os colonos adotaram para otimizar técnicas indígenas foram o tacho de cobre e o forno, usados para fazer farinha (HoLANDA, 1995).

Nos inventários do termo de Uberaba, os equipamentos que compunham o complexo do milho eram quase onipresentes. De um total de 167 inventários, encontramos monjolos arrolados em 48 deles, fornos em 28 (18 de cobre e 10 de ferro) e moinhos de pedra estavam presentes em 19 documentos.

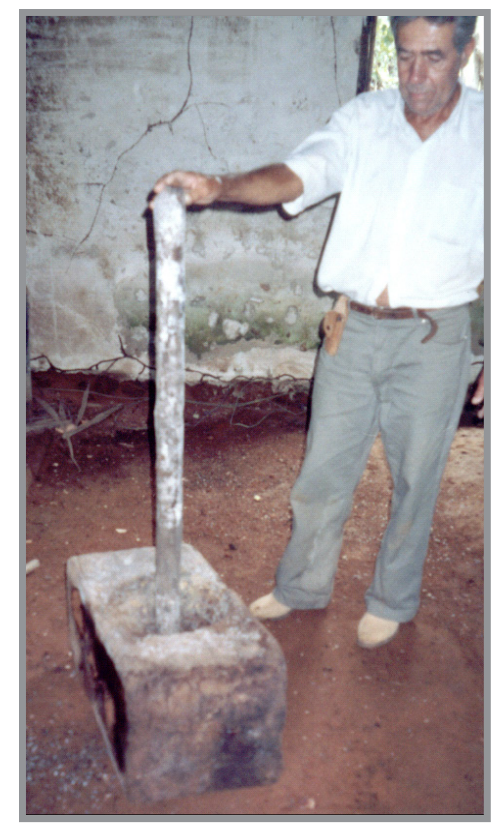

Figura 5: pilão (Nova Ponte - MG).

Fonte: foto de Lourenço, L. A. B. (2002) 
Dentre os inventariados, praticamente todos os que possuíam sítios - isto é, unidades rurais de moradia e produção — tinham monjolos, demonstrando que se tratava de um equipamento básico no beneficiamento de alimentos para os roceiros. Os "fornos de torrar farinha", por seu turno, eram menos corriqueiros, mas em praticamente todos os inventários constavam tachos de cobre, usados para a mesma finalidade, na falta do forno.

Os moinhos de pedra existiam apenas em algumas unidades. Associamos a presença dos moinhos ao número de escravos de cada inventário, e produzimos o gráfico 2. Nota-se que entre os pequenos proprietários de escravos - plantel com menos de 5 cativos — não era comum possuir moinhos, ao passo que encontramos um grande número deles nas mãos de médios proprietários de escravos - entre 6 e 10 cativos - e dos grandes proprietários - mais de 10 cativos. Essa estrutura de distribuição permitenos deduzir que a moagem do milho, apesar de se inserir no rol das atividades
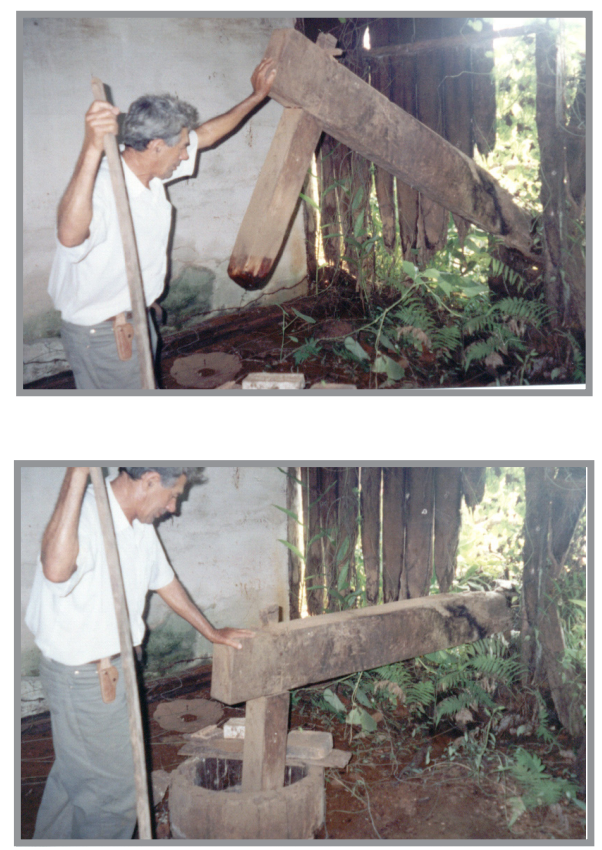

Figuras 6 e 7: monjolo (Nova Ponte, MG).

Fonte: fotos de Lourenço, L. A. B. (2002) 
domésticas, estava presente apenas em fazendas com pelo menos um razoável número de escravos, corroborando a informação de Holanda de que o fubá se destinava principalmente à alimentação dos cativos.

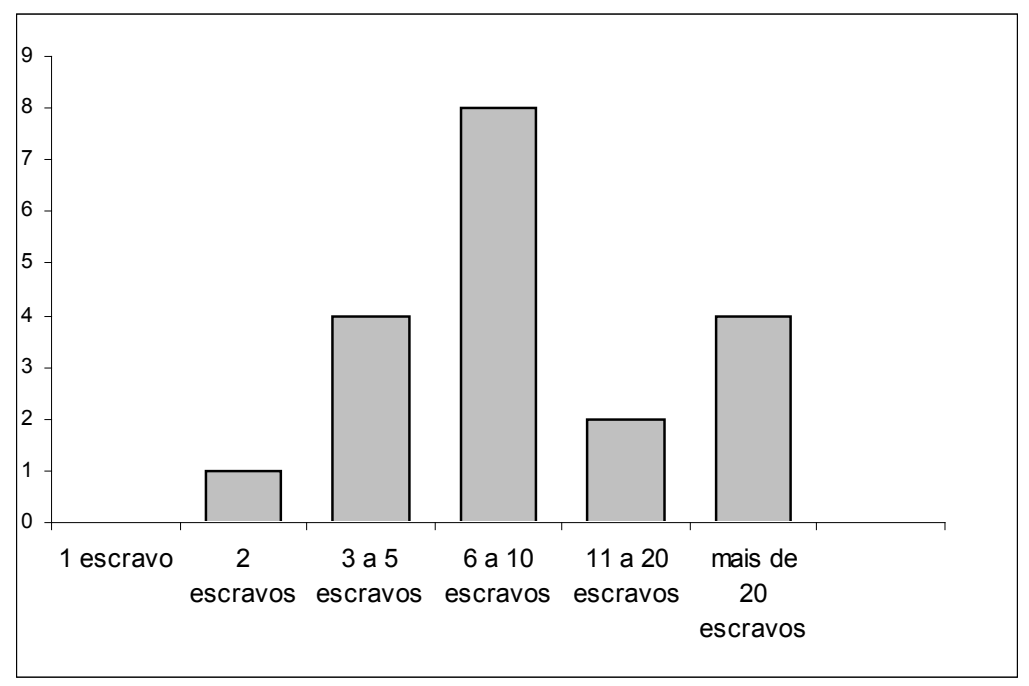

Gráfico 2: distribuição dos moinhos de fubá por fazendas, classificadas por número de escravos. Fonte: APU, inventários post mortem (1822-1861).

Contudo, é possível que os moinhos, nessas unidades escravistas, destinassem-se não só às necessidades domésticas de fubá, mas também a moer o milho produzido nas unidades menores, que pagavam pelo uso deles em espécie. Não temos provas diretas dessa relação de produção nos documentos pesquisados, mas ela era comum, por exemplo, entre os caipiras estudados por Antônio Cândido (2001), ou entre os engenhos do litoral (FerLInI, 1988), lembrando a poia e a maquia, tradicional entre moleiros de Portugal (Holanda, 1995).

Neste item, analisamos dois dos mais importantes complexos técnicos, responsáveis pela obtenção dos principais alimentos energéticos dos sertanejos do interior do Brasil, no período colonial e imperial: o milho e a mandioca. Concluímos pela presença do complexo do milho no Triângulo Mineiro na primeira metade do século XIX, mas não existem indicadores da presença de uma tradição mandioqueira na mesma região. 
A seguir, veremos como se organizava a produção têxtil na região em estudo, no mesmo período.

\section{Fios e panos}

Se os complexos do milho e da mandioca foram, em grande parte, absorvidos das práticas indígenas praticamente sem grandes mudanças, o mesmo não se deu com as técnicas de fiação e tecelagem. Embora o algodão indígena ou "algodão da terra", arbóreo, tenha sido mais utilizado que o algodão asiático ou "algodão da Pérsia", herbáceo, todas as técnicas de beneficiamento (descaroçamento), fiação e tecelagem foram trazidas pelos colonos, com base nas experiências acumuladas não só em Portugal, mas também no Império Português.

Holanda (1995) assinala que a introdução do algodão herbáceo no Brasil ocorreu somente na década de 1790, por influência dos técnicos agrícolas ilustrados, vindos no período mariano-joanino. Segundo esse autor, apesar da maior produtividade deste — 5 a 6 vezes maior que a do algodão indígena —, as primeiras tentativas de popularizá-lo não foram bem sucedidas, por causa das dificuldades de aclimatação, e talvez por não se adaptar bem às técnicas locais, principalmente ao descaroçador a manivela.

Dessa forma, é provável que, em toda a primeira metade do século XIX, o algodoeiro "da terra" tenha sido a única espécie cultivada em Minas Gerais. Saint Hilaire referiu-se somente a algodoeiros arbóreos em Peçanha, uma das principais regiões produtoras da província: "uma plantação de algodoeiros dura em média de 5 a 6 anos [...] e não produzem senão ao cabo de 2 anos" (2000, p. 172). Em nossa região de estudo, o algodão arbóreo aparece referido em alguns documentos, como na carta de padre Leandro, de 1827, onde se lê: "vi pé de algodão que um homem subiu por ele acima até a altura de 14 palmos, e me disseram que esperavam colher meia arroba na primeira panha e da segunda mais de oito libras" (PONTES, 1978, p. 91).

Uma vez colhidos os capulhos, o artefato usado na primeira etapa do beneficiamento de algodão era o descaroçador, máquina rústica derivada da churka indiana, e que se difundiu até Portugal pelas mãos dos árabes. A mais antiga referência a seu uso no Brasil é do Autor Anônimo, em 1618, no Nordeste. Em São Paulo, seu uso generalizou-se em 1680, e de lá provavelmente se 
difundiu para Minas Gerais (HoLANDA, 1995). Saint Hilaire assim descreveu o instrumento, em Peçanha:

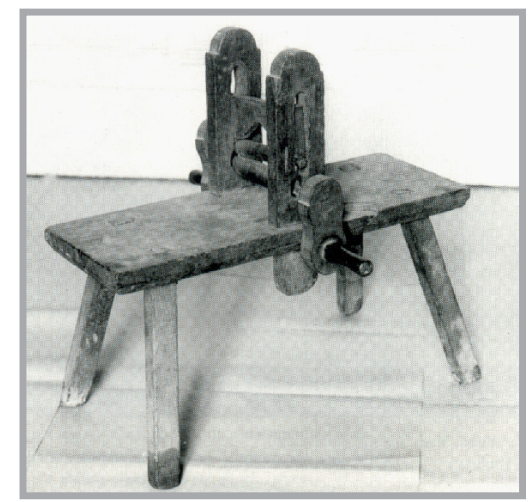

Figura 8: descaroçador de algodão de Cuiabá (século XVIII). Fonte: Holanda (1995).

Para separar o algodão das sementes se emprega uma pequena máquina portátil que se compõe de duas colunas, nas quais se apóiam outros tantos cilindros do comprimento de cerca de um pé [33 cm], da grossura de um dedo e muito aproximados um do outro. Colocam-se os flocos de algodão a um lado dos cilindros e faz-se girar estes em sentido contrário com o auxílio de manivelas colocadas do lado de fora dos montantes. Os cilindros pegam o algodão, puxam-no com a sua rotação, fazem-no passar para o outro lado da máquina, e as sementes ficam do lado em que foram colocados os flocos (2000, p. 172).

$\mathrm{O}$ instrumento não sofreu nenhuma mudança, em seus sucessivos deslocamentos, da São Paulo seiscentista até o Triângulo Mineiro de apenas algumas décadas atrás. A descrição de Saint Hilaire, feita no Norte Mineiro em 1819, corresponde precisamente ao instrumento usado pelos paulistas do século XVIII (figura 8). A descrição que obtivemos de um antigo morador da região rural de Patos de Minas, que manipulava o aparelho em sua infância, na década de 1940, coincide pontualmente com a do botânico francês:

O descaroçador é feito de madeira dura e bem seca, uma vez que necessita de ajustes milimétricos. Compõe-se de longo e pesado banco, tendo ao centro 
duas moendas presas por duas colunas laterais, na altura de mais ou menos vinte centímetros. Essas moendas, uma para cada lado, prendem-se a eixos fixos nas colunas laterais. Os eixos ficam sobrepostos e bem ajustados entre si e às colunas. Para descaroçar o algodão utiliza-se da mão de obra de dois trabalhadores, que ficam assentados, de frente um para o outro, de cada lado do grande banco. Cada um, com a mão direita, aciona a moenda de forma que os eixos giram em sentido opostos. O trabalhador que fica do lado esquerdo do banco é o alimentador, isto é, aquele que coloca o capucho no descaroçador. ${ }^{29}$

Segundo Holanda (1995), o descaroçador rústico resistiu às inovações tecnológicas, inclusive ao saw-gin, inventado no sul dos Estados Unidos no final do século XVIII, que multiplicava exponencialmente a produtividade do descaroçamento. A razão era que o descaroçador primitivo adaptava-se melhor do que qualquer outro à fibra indígena. $\mathrm{O}$ modelo americano destruía as fibras longas, produzidas pelo algodão arbóreo, sendo mais bem adaptado ao algodão herbáceo, de fibra curta. Assim, a permanência de uma técnica rústica se explicaria não por um suposto apego ao "atraso", mas a uma melhor adaptabilidade às características do produto nativo.

Nos inventários do termo da vila de Uberaba, os descaroçadores aparecem referidos em sete inventários, desde 1827. É possível que fossem mais comuns do que deixa transparecer a leitura dos documentos, como se pode deduzir pela presença das rodas de fiar, descritas na maioria dos inventários: é improvável que as famílias dispusessem de rocas e não de descaroçadores. A razão da sua ausência, em moradias que dispunham dos demais elementos do complexo da fiação, é que se tratava de artefatos de fácil feitura, e por isso muito baratos, sendo, na maioria das vezes, ignorados pelos inventariantes. Em 1828, um descaroçador era avaliado em 640 réis, algo como metade do preço de uma enxada velha. ${ }^{30}$

A carda e a fiação eram outras duas etapas que contavam com técnicas exclusivamente ibéricas. O primeiro dos dois processos era realizado por dois tipos de instrumentos: a carda de arco, instrumento simples consistido de uma vara arqueada unida nas extremidades por uma corda; e a carda de espículas, um par de escovas que eram presas uma a cada mão. O segundo processo

29 Geraldo Lourenço Castro, depoimento escrito (02/05/2002).

30 APU, inventário de Miguel Martins Morgado (07/07/1828), maço N35, caixa 459. 
consistia no uso da roda de fiar, uma roda unida a um pedal e a um fuso, no qual eram enoveladas as linhas de algodão, também este um instrumento trazido de Portugal (HoLANDA, 1995).

Holanda (1995) menciona que a carda de arco era a mais usada em São Paulo, até o século XVIII. Saint Hilaire descreve somente o uso da carda de arco, em Peçanha, Minas Gerais: "para cardar o algodão, existe um pequeno arco cuja corda pode ter comprimento de pé e meio” (2000, p. 172). É provável que esse fosse o instrumento de carda usado no Triângulo Mineiro, na primeira metade do século XIX. Nos inventários de Uberaba, é notável a ausência de qualquer referência a cardas, antes de 1850. Isto se dava provavelmente pelos mesmos motivos da quase ausência de descaroçadores: um instrumento tão simples não teria merecido a atenção dos inventariantes.

Contudo, a referência às cardas torna-se muito freqüente após essa data, e por uma razão: tratava-se, a partir de então, das escovas de cardar, um instrumento mais sofisticado e, por isso, mais valorizado. De fato, todas as referências a ele aparecem como "um par de cardas", ${ }^{31}$ o que, segundo Holanda, "a simples circunstância de serem elas avaliadas aos pares serve para mostrar que não se tratava de arcos, ou batedeiras para capulhos" (1995, p. 226).

Nos depoimentos que recolhemos de antigos moradores da região dos anos 1910 e 1920 (Tupaciguara ${ }^{32}$ e Santa Maria ${ }^{33}$ ), a única carda que conheciam era a de espículas. Assim, podemos situar provavelmente em meados do século XIX o início da substituição da carda de arco pela carda em escova, no Triângulo Mineiro.

A tecelagem, em toda a província de Minas, era feita nos teares horizontais que, segundo Holanda (1995), são de origem ibérica (figura 9). Tanto a fiação quanto a tecelagem tiveram grande desenvolvimento na capitania - depois província - de Minas Gerais no final do século XVIII e início do XIX. Saint Hilaire (2000) encontrou nessas atividades a razão da prosperidade do termo de Minas Novas, no Vale do Jequitinhonha, comarca do Serro do Frio.

Nessa região, de solos e clima adequados ao cultivo do algodão, a fiação e a tecelagem faziam dos tecidos e rendas seu principal produto, vendido tanto para a Bahia quanto para o Rio de Janeiro, de onde inclusive era exportado: "o termo de

\footnotetext{
31 APU, inventário de Antônio Francisco de Assis (04/05/1850), maço N14, caixa 470.

32 Guiomar Maria da Silva, depoimento gravado (02/05/2002).

33 Hélio Rodrigues da Cunha, depoimento gravado, (15/01/2002).
} 
Minas Novas é bem conhecido pelos comerciantes da Europa pela excelência de seu algodão" (p. 194). Em Vila do Fanado, ${ }^{34}$ capital do termo, "fazem-se cobertores de algodão [...], de que uma parte se expede para o Rio de Janeiro" (p. 223). Nos arredores daquela vila, em Chapada, ${ }^{35}$ os moradores não produziam o algodão, mas compravam-no das redondezas, para fabricar cobertores (p. 225).

A produção de algodão e tecidos também era uma atividade importante na comarca do Rio das Mortes, que o cronista visitou em 1819 — embora não tanto quanto no Serro do Frio. A área do algodão, que se iniciava nos arredores de São João Del Rei, estendia-se por todo o Oeste da comarca, ao longo da Picada Nova de Goiás, chegando a Araxá. Em São João, Saint Hilaire assinalou que "a cultura do algodoeiro é em geral feita em vários pontos da comarca, [...] tais como Queluz [...], São João Del Rei, Vila da Campanha” (1974, p. 102). Em Pium-i, já no Oeste de Minas, nos arredores da Picada de Goiás, reparou que "seus habitantes [...] derrubam as matas dos arredores [...] e nelas plantam principalmente algodoeiros, que se dão muito bem na região" (1975 b, p. 95).

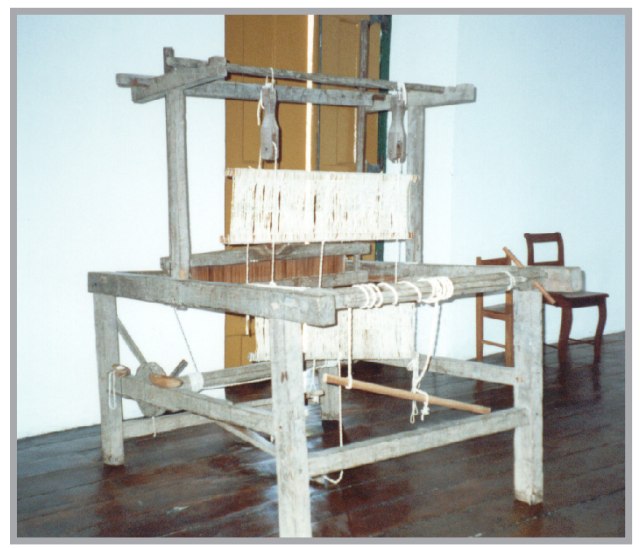

Figura 9: tear horizontal (Goiás Velho, GO).

Fonte: foto de Lourenço, L. A. B. (2002)

O algodão também era plantado e vendido ao Rio de Janeiro pela região de Araxá e Patrocínio. Saint Hilaire relatou que o algodão dessa região "era

\footnotetext{
34 Hoje Minas Novas.

35 Hoje Chapada do Norte.
} 
despachado para o Rio de Janeiro. Até Barbacena esse produto é geralmente transportado em carros de boi, que levam 80 arrobas, e a partir dessa cidade a carga é passada para o lombo de burros" (1975 b, p. 136).

Essa tradição algodoeira chegou também ao então recém-colonizado Sertão da Farinha Podre, pois Uberaba já exportava a fibra em 1819. O naturalista francês, naquela data, escreveu que "as terras da Farinha Podre são igualmente favoráveis à cultura do milho, da cana de açúcar, do feijão e do algodão, mas unicamente este último é exportado" (1975 a, p. 151).

Se uma parte do algodão do Extremo Oeste de Minas era exportado in natura, a maior parte, contudo, era usada nas manufaturas domésticas. Nisso, a região igualava-se às demais da província, onde a produção têxtil, apesar de artesanal, alcançara a auto-suficiência.

Em todo o território mineiro, no final do século XVIII e início do XIX, desenvolveu-se uma próspera manufatura têxtil que, em algumas regiões como o Serro do Frio ou Rio das Mortes, passou até mesmo a exportar tecidos para as demais regiões do Brasil. Mesmo a proibição feita à atividade têxtil, pelo alvará de 5 de janeiro de 1785, não afetou Minas, pois a produção da capitania, que consistia quase que só de tecidos de algodão, era a única exceção feita por essa lei. Com a chegada da Corte, em 1808, o Rio de Janeiro tornou-se um importante mercado, o que aqueceu a produção mineira e permitiu que ela ultrapassasse o âmbito doméstico, gerando excedentes comercializáveis (LiBBY, 1988).

A chegada dos Bragança, todavia, se, por um lado, acabou com as restrições à indústria local, por outro, abriu o mercado brasileiro às importações estrangeiras, que passaram a concorrer com o artesanato doméstico. Isso condenou ao desaparecimento a manufatura têxtil doméstica de São Paulo (HOLANDA, 1995), mas o mesmo não ocorreu com Minas. Segundo Libby, a extraordinária prosperidade das manufaturas têxteis mineiras, mesmo frente à concorrência dos produtos importados, deveu-se a um fator de ordem geográfica, representado pela barreira montanhosa:

[...] os custos de transporte oneravam o preço dos tecidos importados em Minas. Assim, a indústria doméstica contava com a proteção de uma barreira natural. [...] nas primeiras décadas do século, graças a essa proteção relativa, a indústria têxtil doméstica mineira pôde se expandir de maneira muito mais expressiva do que qualquer outra região do Brasil (1988, p. 189-190). 
Esse autor analisou as características dessa peculiar indústria oitocentista mineira usando os mapas da população, levantamentos censitários feitos pelo governo da província no início do século XIX, nos quais constam as ocupações das populações de cada localidade. As séries de 1831 a 1840 revelaram um grande número de fiandeiras e tecedeiras, sendo que "em vários distritos as fiandeiras superavam numericamente qualquer outra categoria ocupacional, mesmo a categoria [...] de 'trabalhadores na agricultura"' (1988, p. 197). Verificou que a maiorparte da população feminina de Minas era formada por pessoas que se definiam por esses ofícios: a força de trabalho feminina era a base da maior atividade manufatureira da província do século XIX.

Libby (1988) notou que praticamente em todos os fogos ${ }^{36}$ da província havia pelo menos uma fiandeira ou tecedeira, sem distinção de classe, verificando-se uma tendência ao predomínio da força de trabalho livre na atividade. Desse modo, o caráter doméstico da manufatura têxtil era claro: as rocas e teares funcionavam como uma parte do trabalho dos núcleos familiares, no qual também se incluía a agricultura e o beneficiamento de alimentos. Holanda já chamava a atenção para essa característica da atividade têxtil, falando de São Paulo dos séculos XVII e XVIII:

Mais do que outras atividades manufatureiras, a fabricação de fios e tecidos destinados a uso doméstico andava estreitamente associada, aqui, à vida do lar. Nos sítios da roça, onde quer que existisse mão de obra para o mister, o excesso da produção servira para permutas e pagamentos [...] (1995, p. 218-219).

A força de trabalho escrava (nesse caso, das escravas) funcionava mais como extensão da força de trabalho familiar do que propriamente como base de uma produção escravista. Veremos, no capítulo 5, que assim se dava com toda a produção das unidades familiares que contavam com poucos escravos.

Libby observou que, em toda a província de Minas Gerais, o número de fiandeiras era sempre superior ao de tecedeiras. O fio era o produto final de quase todas as unidades domésticas e, muitas vezes, era vendido para outras regiões. Porém, a principal razão da existência de poucas tecedeiras para muitas

36 Usaremos a terminologia fogo ao referirmo-nos à unidade familiar (que também funcionava como unidade produtiva) reunida geralmente em torno de uma família nuclear. Essa é a terminologia usada nos documentos de época. 
fiandeiras é que estas produziam fios para aquelas, num sistema integrado em que várias rocas supriam um único tear.

Esse sistema, de várias fiandeiras para algumas tecedeiras, é o mesmo que imperava na capitania de São Paulo, desde o século XVII. Estudando inventários seiscentistas, Holanda também encontrou muito mais rocas que teares, e concluiu: "nem todos dispõem de teares, de modo que alguns proprietários devem auferir bons lucros fazendo tecer o algodão próprio e alheio" (1995, p. 215). Em São Paulo, o tecelão recebia uma vara de tecido a cada sete que fabricasse.

Nos mutirões seguidos de festa — que, no Triângulo Mineiro, recebiam o nome de treição - , era comum as mulheres fiarem, enquanto os homens trabalhavam as roças. D'Alincourt descreveu um mutirão em Jundiaí:

[...] em uma casa, em que, nessa ocasião, havia um grande número de pessoas, de ambos os sexos; por ser costume juntarem-se muitos para o trabalho a que chamam muchiron na linguagem indiana; e assim passam a umas a outras casas, à medida que vão findando as tarefas: o trabalho consiste em prepararem $\mathrm{e}$ fiarem algodão, e fazerem roçados nas plantações (1975, p. 49).

Coletamos um relato de uma moradora do meio rural de Tupaciguara nos anos 1920, que descreve o mesmo sistema de organização do trabalho, com as mulheres assumindo a fiação como tarefa coletiva, na treição:

A treição dos fazendeiros [...] era a coisa mais fácil que tinha. Eles cismavam de fazer a treição lá com um fazendeiro, então juntavam um ou dois, e ali combinavam tudo como iam fazer. Se ele tinha pasto para roçar, eles viam lá que tinha muito serviço de pasto para roçar, eles iam lá roçar pasto, se era para plantar [...]. Se fosse tempo de capina era na enxada, se fosse para roçar era na foice. As mulheres iam fiar, iam cardar, descaroçar, tudo de uma vez. Aí eles combinavam tudo e o fazendeiro não sabia de nada, não. Levantava de madrugada, ali eles arranjavam sanfona, arranjavam viola, juntavam aquele monte de gente. Eu cheguei a levar a Íris, pequenina, numa treição que deram no Odilonzinho. ${ }^{37}$

37 Guiomar Maria da Silva, depoimento gravado (15/04/2002). 
Algumas fiandeiras também trabalhavam por encomenda, fiando algodão alheio e sendo pagas com parte da produção. Em 1819, Saint Hilaire, de passagem por Corumbá de Goiás, notou que "as mulheres fiam o algodão e recebem o seu salário na forma de mercadorias" (1975 a, p. 33).

O Oeste Mineiro e o Alto Paranaíba eram as regiões que mais se dedicavam à fiação e tecelagem domésticas. No Triângulo Mineiro, Libby encontrou situação semelhante. Nessa região, "mais de três quartos das mulheres chefes de domicílio eram fiandeiras ou tecedeiras" (1988, p. 203). Assim, as mesmas bases em que se estruturava a fiação e tecelagem em outras regiões da província de Minas Gerais — força de trabalho feminina, caráter doméstico da produção, uso do trabalho escravo como extensão do trabalho livre - provavelmente também existiam na região em estudo. Seria interessante tentar abordar o estudo da manufatura têxtil oitocentista no Triângulo Mineiro usando outras fontes, diferentes das de Libby, a ver se se confirma o quadro traçado pelo autor.

A leitura dos inventários da vila de Uberaba, entre 1822 e $1861,{ }^{38}$ mostra de maneira inequívoca o caráter doméstico e pulverizado da fiação e tecelagem na região. De um total de 167 inventários, 62 deles (37\%) arrolavam rodas de fiar, e $42(25 \%)$ contavam com teares. Assim, aproximadamente um terço das unidades familiares envolvia-se com a atividade de fiação, e uma quarta parte com a tecelagem. A proporção entre unidades domésticas com rodas de fiar e unidades com teares era de aproximadamente três fogos com rodas para cada dois com teares.

Esses números mostram que, embora por certo houvesse algumas unidades domésticas especializadas em tecelagem e outras em fiação, havia um baixo nível de especialização, com grande parte das famílias se ocupando tanto da fiação quanto da tecelagem. Dessa forma, do total de unidades domésticas envolvidas em atividades têxteis, $42 \%$ delas se ocupavam só da fiação, 15\% só da tecelagem, e $42 \%$ da fiação e tecelagem.

No gráfico 3, correlacionamos a presença dos artefatos do complexo têxtil com o plantel de escravas em cada unidade doméstica, pressupondo que a força de trabalho feminina estava associada a esse tipo de atividade. Como se pode verificar, não existia nenhuma correlação entre presença ou número de teares e plantel de

38 APU, inventários post mortem (1822-1861). 
escravas: tanto entre sitiantes modestos, como entre grandes fazendeiros, o número de teares por unidade nunca era superior a um. Constata-se, com isso, o caráter doméstico, e não fabril, da produção têxtil no termo de Uberaba. A correlação entre número de rodas de fiar e número de escravas também era muito fraca, exceto nas fazendas com grandes plantéis, o que sugere que, como já havia adiantado Libby, o trabalho escravo era pouco empregado na atividade têxtil.

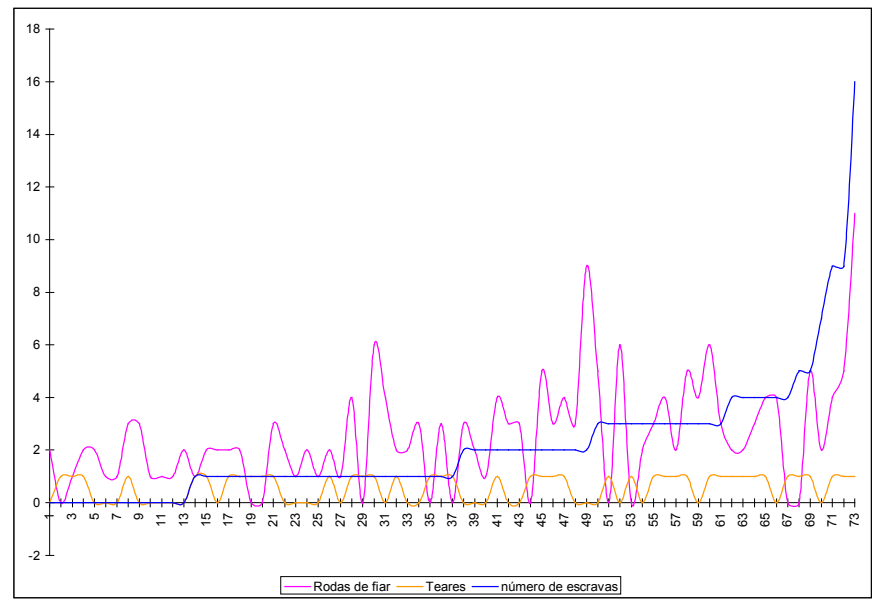

Gráfico 3: correlação entre número de escravas, rodas de fiar e teares em 73 inventários post mortem do termo de Uberaba (1822-1861), distribuída em ordem crescente do número de escravas. Fonte: APU, inventários post mortem (1822-1861).

Esse quadro sugere que, na região, o mundo da fiação e tecelagem muito se assemelhava àquele descrito por Saint Hilaire, em outras regiões de Minas. Na fazenda do alferes Machado, nas proximidades de Peçanha, Vale do Jequitinhonha, observou que "nessa casa todos estavam em atividade, espetáculo que raramente goza o viajante que percorre o Brasil. A senhora Machado cosia; algumas de suas filhas fiavam o algodão, outras faziam renda" (2000, p. 171).

A difusão dos equipamentos técnicos do complexo da fiação e tecelagem entre a população mostra que a mercantilização da produção no nível local era pequena, o que de resto ocorria com grande parte dos gêneros de subsistência, 
dada a baixa divisão social do trabalho. Analisando o inventário do capitão Manuel da Silva Cardoso, comerciante de tecidos de Uberaba, morto em 1841, foi possível conhecer as mercadorias têxteis, ou "fazendas secas", que constavam de seu estoque. ${ }^{39}$ Ali estavam arrolados chitas, riscados sortidos, lenços estampados amarelos, americanos, fustões, paninhos cor-de-rosa, mas nenhum pano de algodão. O comércio local de têxteis, ao que parece, só se ocupava de vender artigos importados, já que grande parte da população produzia ou obtinha por troca direta — os tecidos de algodão usados na vestimenta do dia-a-dia.

Deste modo, o quadro que se revela, relativo à manufatura têxtil no Triângulo oitocentista, é o de uma atividade presente em grande número de moradias, onde mulheres livres - mães, filhas e parentes - e escravas se envolviam nas várias etapas do complexo têxtil — descaroçamento, carda, fiação e tecelagem - como parte das atividades da rotina doméstica. Eventualmente, produziam excedentes — fios e panos — que eram comercializados. Havia pouca especialização nas diversas atividades, embora alguns fogos fizessem só fios, e algumas tecelãs que não fiassem, recebendo encomendas de fiandeiras, talvez fossem pagas com parte do tecido produzido.

A seguir, veremos como a sociedade de pioneiros geralistas tratava a questão da moradia no Triângulo Mineiro da primeira metade do século XIX.

\section{Casas de morada, cozinha e quintal}

A paisagem rural oitocentista do Triângulo Mineiro, que os relatos dos viajantes do início daquele século deixam entrever, resultava de um padrão de ocupação que tendia a manter praticamente desertas as chapadas, enquanto os cultivos, a moradia e o instrumental técnico de beneficiamento se situavam nos vales fluviais. Nas proximidades de Oliveira, Saint Hilaire comentou, ao chegar numa fazenda, que "como todas as outras, fica situada numa baixada" (1975 b, p. 83). No Ribeirão das Furnas, nas proximidades do Rio das Velhas, "o engenho de Furnas fica num vale profundo" (1975 a, p. 139).

39 APU, inventário do capitão Manuel da Silva Cardoso (08/11/1841), maço N9. 
Esse é o tipo de sítio no qual encontramos as fazendas mais antigas, que sobreviveram daquela época aos dias de hoje, como se vê na figura 10. A razão da escolha desse sítio é, essencialmente, a necessidade da água: esta era obtida pelos regos d'água, desviados dos córregos adjacentes. Além disso, a presença mais comum das terras de cultura nas matas galerias favorecia o cultivo de hortas e pomares. Dessa forma, o sítio deveria estar sempre a jusante de algum pequeno curso d'água, que pudesse ser facilmente transposto por estivas ou pinguelas. Raramente, contudo, o sítio escolhido ficava na margem de rios caudalosos, de difícil transposição e sujeito a febres malsãs.

O rego d’água (figura 11) era o que tornava possível não só o beber e o alimentar-se das pessoas e animais, mas também o próprio funcionamento de todo o maquinário rústico necessário aos processos de beneficiamento. Fonte de energia dos monjolos, moinhos, rodas d'água, engenhocas e alambiques, a força mecânica hidráulica só era sobrepujada pela força muscular — humana e animal — na ecologia dos estabelecimentos rurais antigos.

O rego d'água era elemento onipresente nos sítios — nome dado ao conjunto formado por moradia e benfeitorias, tanto de pequenos quanto de grandes proprietários —, nos inventários do termo de Uberaba, entre 1822 e 1861. A dependência em relação ao rego d'água impunha que se localizassem todas as benfeitorias bem próximas umas das outras.

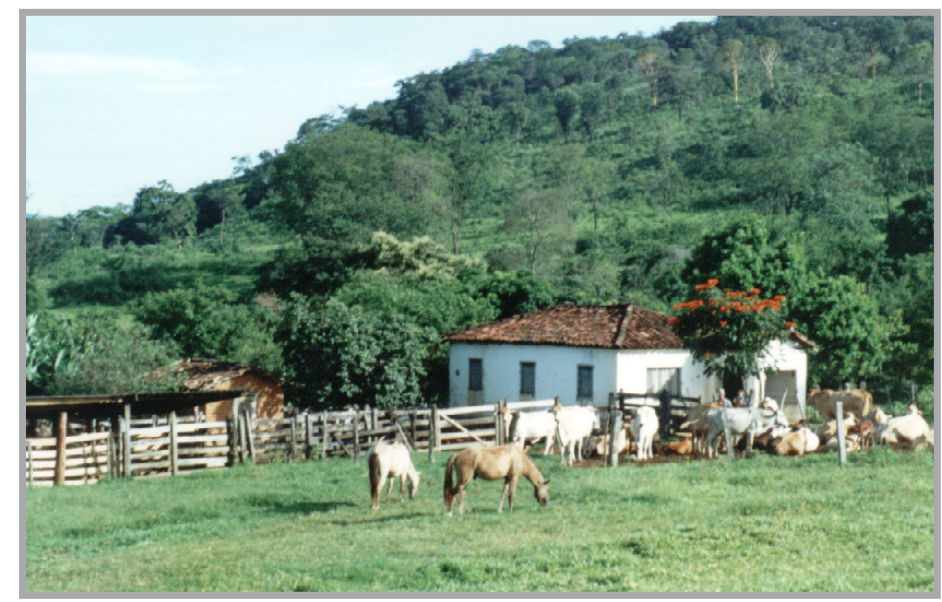

Figura 10: fazenda de gado (Pirenópolis, GO).

Fonte: foto de Lourenço, L. A. B. (2002) (2001). 
Os inventários mostram que os sítios obedeciam a um desenho básico, onde se construíam, contíguos à casa de vivenda, o curral — geralmente feito em madeira aroeira, mas podendo-se usar pedras no lugar dela —; o paiol; o monjolo; e o quintal onde, invariavelmente, constavam "arvoredos de espinhos" (laranjeiras), freqüentemente cafeeiros e bananeiras e, às vezes, jabuticabeiras. Também nesse espaço se encontravam os moinhos de fubá e as engenhocas,

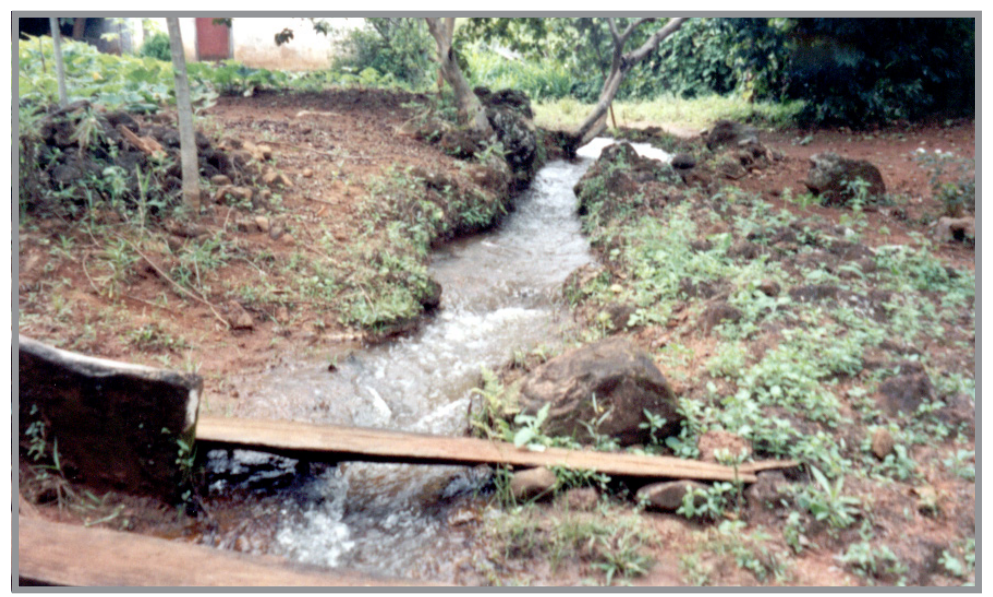

Figura 11: rego d'água e pinguela (Nova Ponte, $\mathrm{MG}$ ).

Fonte: foto de Lourenço, L. A. B. (2002).

quando o sitiante dispunha dessas benfeitorias.

Esse complexo de moradia e trabalho era cercado por aroeira ou valos, de forma a impedir a invasão do gado. Assim, o sítio de João Caetano Barbosa compunha-se, em 1832, de "pequenas casas cobertas de capim, paiol, rego d'água, monjolo, quintal, parte dele cercado de aroeira e cafés e alguns arvoredos de espinhos, um pastinho cercado de valos unido ao mesmo quintal". ${ }^{40}$

A cozinha era uma dependência apartada da casa, normalmente descrita em separado. Por exemplo, no inventário de Maria Joaquina da Silveira lê-se "morada de casas cobertas de telhas com cozinha coberta de telhas". ${ }^{41}$ A cozinha,

\footnotetext{
40 APU, inventário de João Caetano Barbosa (24/04/1832), maço N11, caixa 470.

41 APU, inventário de Maria Joaquina da Silveira (02/11/1827), maço N5.
} 
às vezes, era construída com apreço maior do que a própria casa de morada: é o que se percebe no inventário de Agma Agostinha Souza Benício, de 1843, que possuía "casas de vivenda cobertas de capim, cozinha coberta de telhas, paiol metade coberto de telhas". ${ }^{4}$

Ausências notáveis, nos inventários pesquisados, foram as habitações de escravos. Do total de 167 documentos lidos, senzalas foram referidas em apenas três deles, todos proprietários de grandes plantéis de cativos. Essas habitações coletivas de escravos foram citadas somente nos inventários do capitão Antônio José de Araújo, ${ }^{43}$ senhor de 21 escravos em Dores do Campo Formoso, em 1838; no do tenente Joaquim Silva Oliveira, ${ }^{44}$ poderoso fazendeiro de Uberaba, dono de um plantel com 42 cativos; e no de um senhor de engenho de Carmo dos Morrinhos, capitão José de Miranda Ramalho, ${ }^{45}$ dono de 33 cativos. Assim, os inventários não noticiam, por exemplo, onde viviam os nove escravos de José Gonçalves Lima, ${ }^{46}$ em 1835, pois seu sítio foi descrito como "casas de vivenda, paiol coberto de capim com seu quintal cercado de madeira, com plantações de café, arvoredos de espinhos, curral e engenhos de pilões já velhos", e só.

Essa ausência também foi percebida por Sheila Castro Faria, em seu estudo feito em inventários post mortem da região de Campos dos Goitacases entre os séculos XVIII e XIX. A autora aventou três hipóteses para o fato:

A primeira, e mais evidente, é que as senzalas eram tão destituídas de valor que não mereciam avaliações precisas [...]. A segunda hipótese é a de que a casa dos escravos era construída por eles próprios, e de sua propriedade. [...] Mais provável, e é a terceira hipótese, é que o local onde dormiam os escravos se localizasse dentro das casas de morada do proprietário, sendo, mais uma vez, a designação plural "casas de morada" que definia não só o complexo de moradia e beneficiamento como também um lugar onde dormiam pessoas diferenciadas (1998, p. 368).

Diversamente da autora, tendemo-nos mais para a segunda hipótese por ela aventada. Os relatos dos viajantes joaninos não deixam dúvidas

\footnotetext{
APU, inventário de Agma Agostinha Souza Benício (04/09/1843), maço N44.

APU, inventário de Antônio José de Araújo (20/03/1838), caixa 459.

APU, inventário de Joaquim Silva Oliveira (06/03/1839), maço N7, caixa 461.

APU, inventário de José de Miranda Ramalho (03/08/1844), maço 2.

APU, inventário de José Gonçalves Lima (05/11/1835), maço N122.
} 
quanto à exigüidade e precariedade das habitações sertanejas, mesmo quando pertencentes a senhores abastados. Eschwege descreveu, em Patrocínio, a Fazenda do Salitre, "que pertence a um dos mais nobres e ricos fazendeiros, que é também juiz e dedica-se à criação de gado", o qual, não obstante, vivia numa casa onde "as paredes da moradia, pequena e baixa, feitas de barro, estavam inteiramente esburacadas. A porta estava semi-obstruída por varas, que impediam a entrada dos porcos" (1996. p. 110). Pelo menos no contexto do Extremo Oeste Mineiro, as rústicas habitações sertanejas não poderiam abrigar a família do proprietário — geralmente numerosa — e mais as famílias escravas.

Os relatos dos viajantes permitem supor que os escravos viviam em habitações unifamiliares, vizinhas à casa do proprietário, e compondo o que os documentos da época denominavam sítio. Sempre que se referiram às moradias de escravos, os cronistas falaram de choupanas ou taperas construídas nas proximidades da casa dos senhores, muitas vezes, dela pouco se diferenciando, mas sempre dela apartadas. Nas vizinhanças de Madre de Deus, ${ }^{47}$ no Alto Rio Grande, em 1819, Saint Hilaire assinalou que:

Descrever uma das fazendas da comarca de São João significa descrever todas, pois em geral são construídas segundo o mesmo modelo. Um muro de pedras rústicas mais ou menos da altura de um homem cerca um pasto bastante vasto, no fundo do qual se enfileiram as choças dos escravos, os galpões para beneficiamento ou depósito dos produtos agrícolas e a casa grande. Esta, de pau-a-pique e coberta por telhas, é construída ao rés do chão [grifos nossos] (1975 b, p. 56).

Indo em direção ao Oeste Mineiro, pela Picada de Goiás, nas proximidades da Serra da Canastra, o naturalista relatou:

Já nos limites do sertão, as casa da sede das fazendas se compõem de várias edificações isoladas, mal construídas e dispostas sem ordem, no meio das quais dificilmente se distingue a residência do proprietário. Citarei a de Dona Tomásia, localizada entre o povoado de Pium-i e a Serra da Canastra. A propriedade era de extensão considerável e vi vários escravos e gado, e numerosos porcos. Entretanto,

47 Hoje Madre de Deus de Minas. 
em meio a várias casinhas que serviam de celeiros e senzalas, a dona da fazenda ocupava uma miserável cabana [...] [grifos nossos] (p. 75).

Nas proximidades de Araxá, observou sobre os fazendeiros que "as casas em que vivem são pequenas e escuras, e, mesmo nas fazendas um pouco mais prósperas, a que pertence ao dono da propriedade não se diferencia do alojamento dos escravos" (1975 b, p. 119). Em Goiás, numa fazenda próxima a Santa Luzia, “a casa do proprietário, coberta de palha, difere pouco da dos escravos” (1975 a, p. 23).

Essa hipótese de que, em muitos casos, os escravos viviam em ranchos unifamiliares vizinhos às moradas de seus senhores, já havia sido aventada por Robert Slenes (1999). Esse historiador, estudando as habitações de escravos de Campinas do século XIX, concluiu que as grandes habitações coletivas - senzalas no sentido estrito, ou senzalas-pavilhão, no dizer do autor - eram freqüentes em fazendas com grandes plantéis de cativos. Já nas fazendas com plantéis menores, mais comuns eram as habitações individuais ou unifamiliares, construídas pelos próprios escravos, sem janelas e cobertas de palha ou folha de buriti, num estilo que remonta a tradições construtivas da África Central. Rugendas retratou uma dessas habitações em um de seus desenhos, que pode ser visto na figura 12. Saint Hilaire deixou uma descrição dessas moradias:

[...] se compunha de uma pequena varanda em que se cozinhava, dum casebre que não passava de um alpendre coberto de esteiras e [...] de uma pequena choça em que a luz penetrava por todos os lados pelos buracos que a terra, caindo, deixara nas paredes. [...] Seu interior era dividido em quartos por um septo formado unicamente por estacas justapostas. Uma mesa, um tamborete e vários giraus ou leitos rústicos aplicados contra as paredes, formavam todo o mobiliário dessa mesquinha morada (2000, p. 169).

Dessa forma, as senzalas arroladas nos inventários post mortem de Uberaba do século XIX provavelmente se referiam às senzalas-pavilhão, isto é, habitações coletivas de cativos, já que estavam incluídas no patrimônio de senhores de grandes escravarias. Saint Hilaire, nas proximidades de Meia 


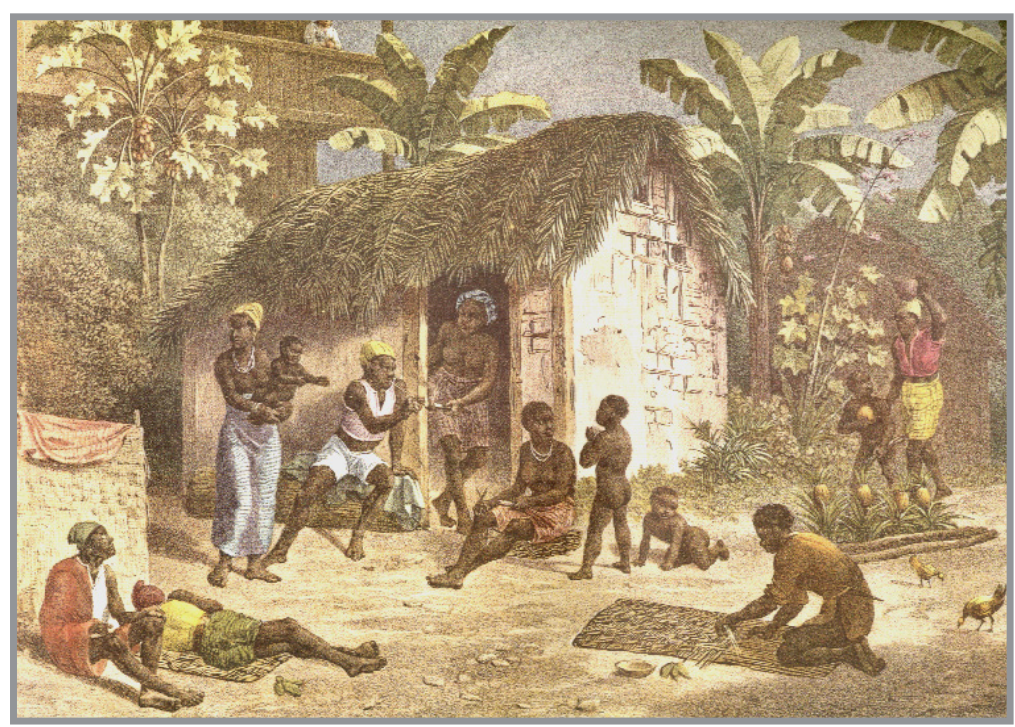

Figura 12: habitação de negros.

Fonte: Rugendas (1998).

Ponte, ${ }^{48}$ em Goiás, descreveu uma dessas senzalas, numa fazenda onde o outro lado da casa do proprietário "era constituído pelos alojamentos dos escravos casados. Esses alojamentos eram cobertos de telhas e divididos em cubículos por paredes até certa altura” (1975 a, p. 98).

Outra ausência intrigante nos inventários é a das moradias de um grupo de inventariados que, a despeito disso, eram proprietários de modestos a razoáveis patrimônios rurais e mancípios. Fortunato Nogueira da Cruz, ${ }^{49}$ por exemplo, era dono de vinte e duas cabeças de gado, trinta e sete porcos e quatro cavalos, além da escrava Claudiana e de seu filhinho Francisco, de dois anos. Com esse rebanho, um machado e três enxadas, sustentava seus cinco filhos menores, até ser assassinado pela esposa Maria Felizarda, em 1847. A questão é: onde Fortunato trabalhava para prover sua família, já que não constam terras em seu patrimônio? E - mais importante — onde vivia até seu infeliz desfecho, já que sequer um imóvel aparece arrolado em seu inventário?

\footnotetext{
48 Hoje Pirenópolis.

49 APU, inventário de Fortunato Nogueira da Cruz (27/09/1847), maço N14.
} 
Fortunato, e como ele muitos outros roceiros do Triângulo Mineiro nos primeiros anos do século XIX, era possivelmente um agregado - termo que designava aqueles que se instalavam em terra alheia, sem ônus. Os agregados eram com freqüência referidos pelos cronistas. Saint Hilaire registrou que "os fazendeiros que possuem grandes extensões de terras dão permissão aos pobres para cultivarem o que quiserem" (1975 b, p. 97).

Esses camponeses sem terra viviam geralmente nos arredores da morada do proprietário, e seus ranchos rústicos misturavam-se às choças dos escravos e às edificações das benfeitorias. Nas proximidades de Santa Luzia, o botânico francês encontrou um "sítio, que abrigava duas ou três famílias, compunha-se de algumas casinhas feitas de barro cinzento, umas cobertas de palha, outras de folhas de buriti" (1975 a, p. 22). Em Caldas Novas, no sítio de Francisco Alves, encontrou "uma dúzia de casinhas esparsas. Uma delas pertencia ao proprietário e as outras eram habitadas por escravos e agregados. Todas, porém, tinham uma aparência igualmente miserável, sendo impossível distinguir a do dono" (p. 110). Em Catalão, "paramos no Sítio do Riacho, composto de três a quatro casebres pertencentes a diferentes pessoas" (p. 123).

Existem algumas indicações nos inventários que sugerem essa disposição das habitações de agregados e escravos, dispersas nos arredores da casa do proprietário. Em alguns casos, essa referência é explícita. Por exemplo, no inventário de Maria Rodrigues da Silva, ${ }^{50}$ havia "um sítio com vários ranchos de capim, rego d'água e um monjolo, com seu quintal e arvoredos de espinho" em sua Fazenda Bagagem, em 1833. No inventário de Policarpo José de Lima, ${ }^{51}$ constavam "uma casa de madeira coberta de telha [...] e outros ranchos todos cobertos de capim, já usados".

Quanto às técnicas de edificação das moradias, os sertanejos contavam com as opções trazidas da região central da província de Minas Gerais. Em todo o Brasil, os colonos utilizaram um conjunto de técnicas de edificação (taipa de pilão, taipa de mão, adobe, alvenaria de tijolo, pedra e cal) originadas de diferentes regiões de Portugal, e trazidas por construtores ou pelos próprios imigrantes da Península Ibérica. A seleção entre uma ou outra técnica dependeu de determinantes históricos e ambientais locais, em cada região do Brasil

\footnotetext{
50 APU, inventário de Maria Rodrigues da Silva (5/11/1833), maço N7.

51 APU, inventário de Policarpo José de Lima (8/02/1837), maço N8, caixa 461.
} 
(Mello, 1985). Nesse caso, parece que a influência das técnicas de edificação indígenas, inadequadas para o tipo de família nuclear luso-brasileira, restringiuse apenas à cobertura de sapé dos ranchos (Lemos, 1999).

Não só em Minas, mas em todo o Brasil, a primeira solução para a moradia surgiu sob a forma dos ranchos, que consistiam de um plano básico com

quatro esteios de pau roliço, quatro frechais e uma cumeeira ao alto; roliços também os caibros que receberão as fibras vegetais de cobertura: sapé, folhas de palmeira etc. [...] fechando-se na periferia com tramas ainda de paus roliços e varas, esqueleto que serviria para a sustentação do barro com que se acaba (Mello, 1985, p. 96).

À medida, contudo, que a ocupação se tornava mais antiga, melhoramentos iam sendo agregados à moradia: telhas de barro no estilo "de canal”, paredes de adobe, reboco e caiação (Mello, 1985). O caráter recente da ocupação foi o fator responsável pelos comentários dos viajantes sobre a precariedade das habitações triangulinas, dos primeiros anos do século XIX. Saint Hilaire descreveu um desses ranchos, na Serra da Canastra:

São construídas rusticamente com paus cruzados e barro, que se desprende facilmente. Um capim miúdo, arrancado com raízes e a terra que as envolve, serve-lhe de cobertura. Seu interior é dividido por tabiques em minúsculos cômodos escuros, cujo único mobiliário consiste num par de tamboretes e alguns catres miseráveis (1975 b, p. 105).

Os inventários post mortem das primeiras décadas do século XIX mostram essa rusticidade das habitações dos primitivos ocupantes do Triângulo Mineiro, mesmo entre os fazendeiros de maiores posses. O fazendeiro Antônio Francisco dos Santos, ${ }^{52}$ por exemplo, possuía grande cabedal em 1829, constituído por vinte e dois escravos, 117 cabeças de gado e a Fazenda Piracanjuba, de 11:600\$000. No entanto, residia em uma casa coberta da capim.

Em regiões mais remotas do interior do Brasil, ainda hoje, podem ser vistos exemplares dessa arquitetura rural rústica (figura 13). Consistem do uso de uma estrutura de madeira (baldrames, frechais e esteios), preenchida pela

52 APU, inventário de Antônio Francisco dos Santos (15/06/1829), maço N3, caixa 459. 
taipa de mão ou pau-a-pique (figura 14), ou em alguns casos, por tijolos de adobe (figura 15), e coberta pelas folhas do sapé ou buriti.

Verificamos, contudo, mudanças diacrônicas nessa arquitetura rural, ao longo da primeira metade do século XIX, no termo de Uberaba. Se, na década de 1820, os telhados de capim cobriam $80 \%$ das moradias, pelas descrições dos inventários, nas décadas seguintes, foram dando lugar, gradualmente, às coberturas de telhas de cerâmica, até praticamente

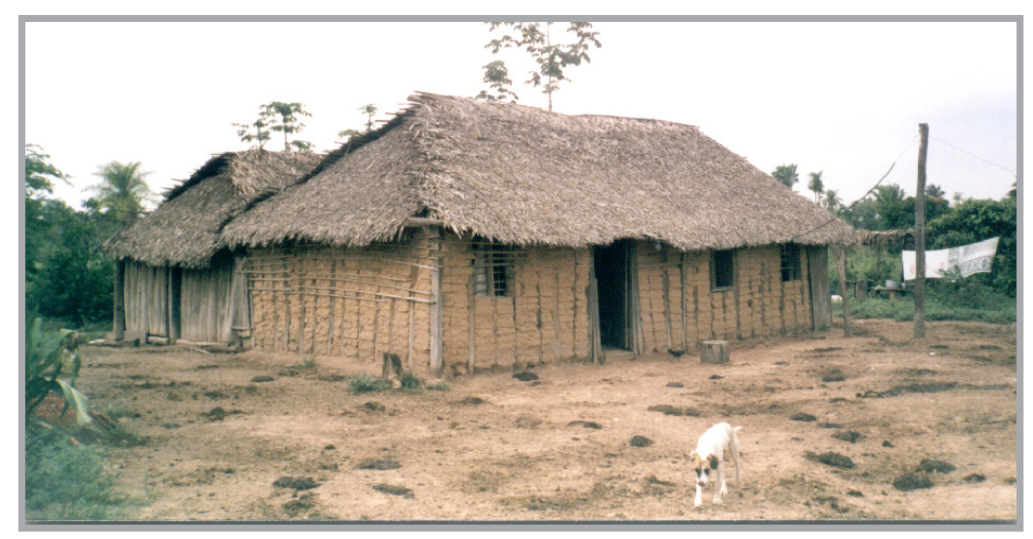

Figura 13: moradia rural coberta de sapé (Piraquê, TO).

Fonte: foto Nataniel Magela de Lima (2001).

desaparecerem nos anos 1850, como mostra o gráfico 4. A partir de 1854, as casas deixaram de ter os telhados descritos nos inventários, o que leva a supor que as coberturas de telhas passaram a predominar amplamente, já não sendo necessário especificar a natureza do material usado em sua confecção.

Vimos, neste capítulo, algumas das técnicas que compunham o sistema técnico dos imigrantes geralistas, quando da sua chegada ao Triângulo Mineiro, nas primeiras décadas do século XIX. O que se pode perceber é que sua rusticidade, se, de um lado, determinava uma baixa produtividade e obrigava a práticas extensivas, de outro, permitia reduzir a um mínimo o custo de reprodução da força de trabalho. 


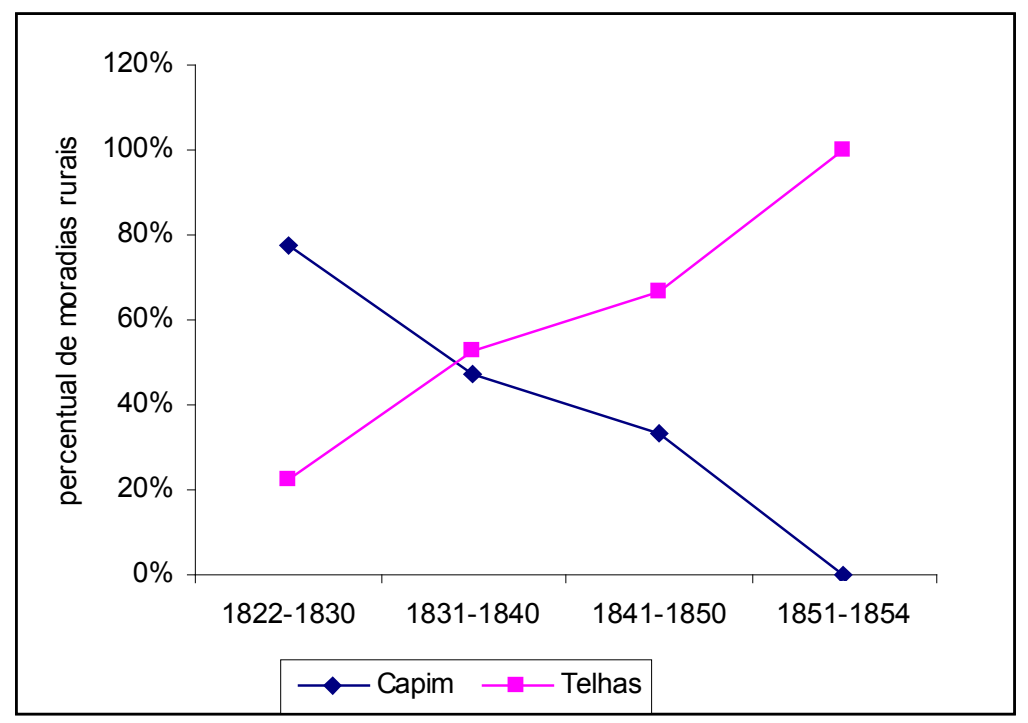

Gráfico 4: técnicas de atelhamento das moradias rurais no termo de Uberaba (1822-1854). Fonte: APU, inventários post mortem (1822-1854).

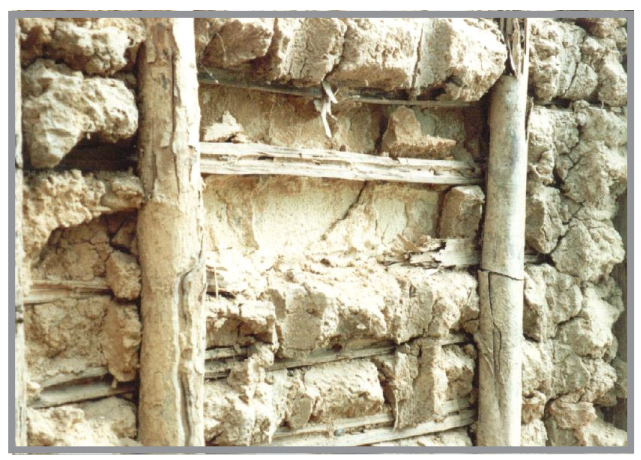

Figura 14: pau-a-pique (Cidade de Goiás, GO). Fonte: foto de Lourenço, L. A. B. (2001). 


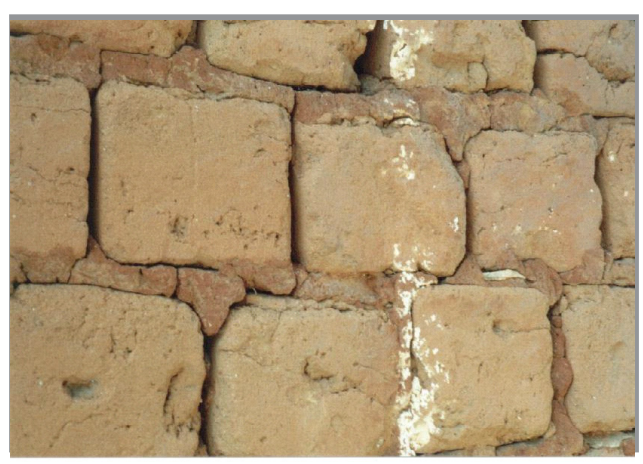

Figura 15: adobe (Pirenópolis, GO). Fonte: foto de Lourenço, L. A. B. (2001).

Esse aspecto permitia, por seu turno, que a economia regional mantivesse certa autonomia frente às crises nacionais ou mundiais, pois podia reduzir a exportação de excedentes sem que sua dinâmica interna fosse muito alterada. Mas, ao mesmo tempo, isso impunha um baixo grau de mercantilização e de liquidez na economia, o que perpetuava a concentração de riquezas. Faremos, no próximo capítulo, uma análise das formas de riqueza e das relações de trabalho no Triângulo Mineiro do século XIX. 